$1-2011$

\title{
Beyond Individualism in Law and Economics
}

Robert B. Ahdieh

Texas A\&M University School of Law, ahdieh@law.tamu.edu

Follow this and additional works at: https://scholarship.law.tamu.edu/facscholar

Part of the Law and Economics Commons

\section{Recommended Citation}

Robert B. Ahdieh, Beyond Individualism in Law and Economics, 91 B.U. L. Rev. 43 (2011).

Available at: https://scholarship.law.tamu.edu/facscholar/1188

This Article is brought to you for free and open access by Texas A\&M Law Scholarship. It has been accepted for inclusion in Faculty Scholarship by an authorized administrator of Texas A\&M Law Scholarship. For more information, please contact aretteen@law.tamu.edu. 


\title{
BEYOND INDIVIDUALISM IN LAW AND ECONOMICS
}

\author{
ROBERT AHDIEH*
}

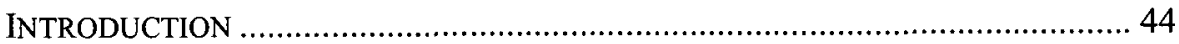

1. THE MEANING(S) OF METHODOLOGICAL INDIVIDUALISM ................. 48

A. The Origins of Methodological Individualism ............................ 49

B. Individualism as Ought, Is, and How ...................................... 52

C. Individuals and Institutions in Explanations ............................... 53

II. THE LIMITS OF METHODOLOGICAL INDIVIDUALISM .......................... 57

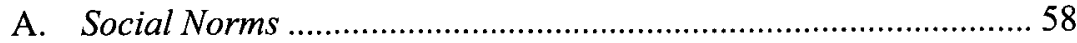

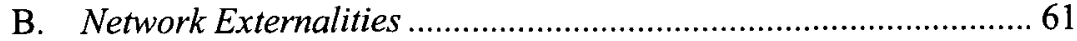

C. Coordination Games ............................................................... 62

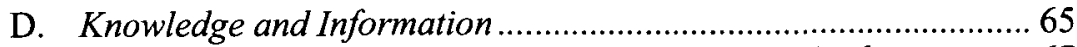

E. Individualism and Interdependence in Economic Analysis .......... 67

III. THE CONSEQUENCES OF METHODOLOGICAL INDIVIDUALISM............... 70

A. Community and Consent........................................................... 70

B. Change and Evolution in Law and Economics.......................... 74

C. The Regulation of Knowledge and Information........................... 77

D. Crisis and Coordination in the Financial Markets..................... 79

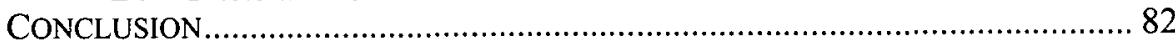

The study of law and economics was built up on two pillars. The first is the familiar assumption of individual rationality. The second, less familiar, is the principle of methodological individualism. Over the last twenty years, law and economics has largely internalized behavioral critiques of the rationality assumption. By contrast, the field has failed to appreciate the implications of growing challenges to its methodological individualism. Where social norms shape individual choices, network externalities are strong, coordination is the operative goal, or information is a substantial determinant of value, a methodology strongly oriented to the analysis of individuals overlooks at least as much as it reveals. Among other potential distortions, indicia of consent

\footnotetext{
* Associate Dean of Faculty, Professor of Law \& Director, Center on Federalism and Intersystemic Governance, Emory University School of Law. My appreciation to Rick Brooks, Bill Buzbee, Amy Cohen, Bob Ellickson, David Fontana, Vicki Jackson, Michael Kang, Don Langevoort, Orly Lobel, David Luban, Richard McAdams, Marc Miller, Jim Nickel, Sten Nyberg, Patrick O'Donnell Mike Seidman, Robert Schapiro, Peter Siegelman, Alex Stein, A.J. Sutter, and Michael Walzer, for their invaluable insights. Thanks also to attendees of the American Law and Economics Association annual meeting, and to workshop participants at Georgetown University, the University of California at Davis, and the University of San Diego. Finally, I am grateful to the Institute for Advanced Study, and to Princeton University's Program in Law and Public Affairs, for their support of my work on this paper.
} 
may be given greater weight than they deserve, the evolution of law and norms may be underemphasized, and our regulation of information, knowledge, and even the financial markets may be flawed. As with the shift toward a more careful approach to rationality, then, attention to the limits of methodological individualism may lead us to a richer account of law and economics.

It is a touchstone of accepted economics that all explanations must run in terms of the actions and reactions of individuals. Our behavior in judging economic research, in peer review of papers and research, and in promotions, includes the criterion that in principle the behavior we explain and the policies we propose are explicable in terms of individuals, not of other social categories. I want to argue today that a close examination of even the most standard economic analysis shows that social categories are in fact used in economic analysis all the time and that they appear to be absolute necessities of the analysis, not just figures of speech that can be eliminated if need be.

- Kenneth J. Arrow ${ }^{1}$

\section{INTRODUCTION}

At the foundation of the neoclassical economics on which law and economics is built, two elements have been seen as essential: first, the assumption of rationality, and second, the mandate of methodological individualism. $^{2}$ Together, these generate the classic construct of homo economicus - the rational actor paradigm that Holmes advanced in law, with his emphasis on the "bad man" as the appropriate focus of legal analysis. ${ }^{3}$

Since Herbert Simon's influential work on "bounded rationality," however, the assumption of rationality has been under siege. ${ }^{4}$ Experimental studies by both economists and psychologists have revealed systematic deviations from rationality across a wide array of settings. ${ }^{5}$ In the works of On Amir, Christine Jolls, Russell Korobkin, Don Langevoort, Orly Lobel, Cass Sunstein, Tom Ulen, and others, in turn, these findings have been applied in the legal

${ }^{1}$ Kenneth J. Arrow, Methodological Individualism and Social Knowledge, 84 AM. ECON. REV. 1, 1 (1994).

${ }^{2}$ See Robert C. Ellickson, Law and Economics Discovers Social Norms, 27 J. LEGAL STUD. 537, 539 (1998).

${ }^{3}$ See Oliver Wendell Holmes, The Path of the Law, 10 Harv. L. Rev. 457, 459 (1897).

${ }^{4}$ See Herbert A. Simon, A Behavioral Model of Rational Choice, 69 Q.J. ECON. 99, 99 (1955).

${ }^{5}$ See, e.g., Werner Guth et al., An Experimental Analysis of Ultimatum Bargaining, $3 \mathrm{~J}$. ECON. BEHAV. \& ORG. 367, 385 (1982) (using ultimatum bargaining games to show that "efficiency does not hold in general"); Amos Tversky \& Daniel Kahneman, Judgment Under Uncertainty: Heuristics and Biases, 185 SCIENCE 1124, 1124 (1974) (describing how heuristics and biases affect the ability to make rational judgments). 
literature - generating the vibrant sub-discipline of behavioral law and economics. ${ }^{6}$ This healthy dialectic of thesis, counterthesis, and synthesis in law and economics' treatment of rationality stands in contrast, however, with its less thoughtful approach to methodological individualism.

Given the origins of their discipline, if nothing else, scholars of law and economics tend to see themselves as methodological individualists. ${ }^{7}$ General descriptions of law and economics are to similar effect, in their reference to methodological individualism as a basic principle of the discipline. ${ }^{8}$ Arguably, in fact, methodological individualism is even more foundational to law and economics than the rationality assumption, serving as a kind of framing constraint, rather than simply an assumption. ${ }^{9}$

As often as not, however, invocations of the mantra of methodological individualism leave the author's intended meaning unclear. ${ }^{10}$ Where a definition is offered, meanwhile, one finds striking variation among authors including the common assertion of definitions that are simply wrong. Beyond such definitional ambiguity lies a more fundamental challenge. While law and economics' orientation to the analysis of individuals is not faced with the kind

6 See, e.g., On Amir \& Orly Lobel, Stumble, Predict, Nudge: How Behavioral Economics Informs Law and Policy, 108 ColuM. L. REV. 2098, 2109-10 (2008); Christine Jolls, Cass R. Sunstein \& Richard Thaler, A Behavioral Approach to Law and Economics, 50 STAN. L. REV. 1471, 1473 (1998); Russell B. Korobkin \& Thomas S. Ulen, Law and Behavioral Science: Removing the Rationality Assumption from Law and Economics, 88 CALIF. L. REV. 1051, 1053 (2000); Donald C. Langevoort, Behavioral Theories of Judgment and Decision Making in Legal Scholarship: A Literature Review, 51 VAND. L. REV. 1499, 1501 (1998) (indicating that work by many researchers has "suggested that there are heuristics, biases and other departures from rational decision-making processes").

7 See, e.g., Ellickson, supra note 2, at 539.

8 See, e.g., Jason Scott Johnston, Law, Economics, and Post-Realist Explanation, 24 LAW \& SOC'Y REV. 1217, 1244 (1990) ("Even the most superficially functional economic analysts of law ultimately adopt a methodological individualist research program."); Fred S. McChesney, Positive Economics and All That, 61 Geo. WASH. L. REV. 272, 295 (1992) (reviewing Frank H. Easterbrook \& Daniel R. Fischel, The Economic Structure of CORPORATE LAW (1991)).

9 See Geoffrey M. Hodgson, Meanings of Methodological Individualism, 14 J. EcoN. METHODOLOGY 211, 211 (2007) ("[I]n so far as economists make their philosophical assumptions explicit, claims to adhere to 'methodological individualism' are uppermost."); see also Patrick B. Crawford, The Utility of the Efficiency/Equity Dichotomy in Tax Policy Analysis, 16 VA. TAX REV. 501, 506-07 (1997) ("The desire to create an objective, scientific basis for the social good is captured in the paramount methodological principle of positivist economics: methodological individualism.").

10 See Hodgson, supra note 9, at 212; Gary Lawson, Efficiency and Individualism, 42 DukE L.J. 53, 58 (1992). Not uncommonly, the dictates of methodological individualism have been equated with the distinct demands of the rationality assumption. No less an authority on methodological individualism than Jon Elster leaves the nexus between the two somewhat unclear. See Jon ElSTER, Nuts AND BOLTS fOr THE SOCIAL SCIENCES 22 (1989) (illustrating the concept of rationality with examples of individual choice). 
of frontal assault that behavioral psychology and economics advanced against the rationality assumption, it is increasingly under pressure as well.

As with critiques of the rationality assumption, much of this challenge comes from within. My emphasis in what follows, as such, is not a sociological preference for methodological holism - an orientation to races, classes, and the like." Rather, I advance the more challenging claim that strands of the economics literature itself undercut the individualistic orientation of law and economics.

Notwithstanding the attention given many of these critical strands including social norms, network externalities, and coordination games - in the legal literature, their conflict with methodological individualism has gone largely unacknowledged. Law and economics scholars have thus failed to appreciate the tensions between these observations and the continued practice of methodological individualism. ${ }^{12}$

The issue, as such, is not simply one of labeling. It is not that students of law and economics call themselves methodological individualists when they are not - although that is surely true in some cases. ${ }^{13}$ The concern herein, rather, is the law and economics literature's persistent emphasis on the individual - its continued attempt to practice methodological individualism even in settings in which that approach is inadequate.

The uncritical invocation of methodological individualism as a foundational principle of law and economics proves to be of real consequence for legal analysis. As I suggest below, it may - among other potential harms - distort legal doctrine in environmental regulation, takings law, and elsewhere; encourage reliance on flawed indicia of consent; and generate inadequate or inappropriate regulation in areas where knowledge or information are important determinants of value. The methodological individualism of law and

"See Ellickson, supra note 2, at 542.

12 Thus, the analysis herein holds implications for a wide array of legal scholarship. See, e.g., Yochai Benkler, Sharing Nicely: On Shareable Goods and the Emergence of Sharing as a Modality of Economic Production, 114 YALE L.J. 273, 358 (2004) (describing a class of "shareable goods" as an instance of the social phenomena at work in various markets); Lisa Bernstein, Private Commercial Law in the Cotton Industry: Creating Cooperation Through Rules, Norms, and Institutions, 99 MicH. L. REV. 1724, 1725 (2001) (examining the "rules, norms, and institutions" that regulate the cotton industry); Michael Klausner, Corporations, Corporate Law, and Networks of Contracts, 81 VA. L. REV. 757, 758 (1995) (questioning the assumption that contracting parties reach socially optimal contractual arrangement that affect neither other contracts nor the parties to other contracts); Mark A. Lemley \& David McGowan, Legal Implications of Network Economic Effects, 86 CALIF. L. REV. 479, 482-83 (1998) (examining the legal implications of network externalities).

13 "In the abstract, the principles of methodological individualism are widely accepted by law and economics scholars. In practice, they are frequently honored in the breach." Lawson, supra note 10, at 56; see also Herbert Hovenkamp, The Limits of Preference-Based Legal Policy, 89 Nw. U. L. REV. 4, 33-34 (1994). 
economics may even help to explain some of our confusion as to how to respond to the recent financial crisis. ${ }^{14}$

The critique herein is not directed, as such, to a narrow group of traditional, classical, or "Chicago-oriented" law and economics scholars. Rather, much of the law and economics literature comes within its ambit. ${ }^{15}$ It is not that scholars of law and economics do not recognize that groups exist, that institutions have influence, or that social dynamics matter. To the contrary, the literature has devoted substantial attention to questions of collectives, social and group dynamics, and the like. These factors are commonly assigned a narrow role in the analysis, however, helping to shape individual preferences, but not serving as direct determinants of observed social outcomes. They are not, as economist Geoffrey Hodgson has put it, made part of the explanation. ${ }^{16}$ That, in fact, is the whole point of methodological individualism. ${ }^{17}$

Consider, by way of example, the place of "community" in law and economics. ${ }^{18}$ In Selling Mayberry: Communities and Individuals in Law and Economics, Gideon Parchomovsky and Peter Siegelman forcefully challenged conventional law and economics accounts of pollution externalities, collective action, and takings. ${ }^{19}$ Law and economics' traditional, individualistic approach to these issues, they argued, could not explain what happened to the town of Cheshire, Ohio, which the owner of a nearby power plant purchased in its entirety. Only by integrating community into the analysis as well, Parchomovsky and Siegelman counseled, could we properly understand the dynamic at work. ${ }^{20}$ For all the force of their argument, however, there was simply no room for community within the entrenched methodological individualism of law and economics. Even as law and economics scholars have cited other strands of Parchomovsky and Siegelman's analysis, not once

14 See infra Part III.

${ }^{15}$ Like Stephen Marglin, in his recent critique of his fellow economists' inattention to community, "I have been urged to recognize the variety within economics by some qualification such as 'mainstream' or 'standard' or 'neoclassical." STEPHEN A. MARGLIN, The Dismal Science: How ThInkING Like AN ECONOMIST Undermines COMMUNiTy 5-6 (2008). I would echo his response, however, that "notwithstanding the variety, the mainstream, in my view, is so dominant that the other streams have become mere trickles." Id. at 6 .

16 See Hodgson, supra note 9, at 220-21.

17 Even Ludwig von Mises - among the founders of methodological individualism acknowledged that "collective wholes" matter. In his view, however, the only way to an understanding of such wholes was through "an analysis of . . . individuals' actions." Ludwig von Mises, Human Action: A Treatise on Economics $42-43$ (2d ed. 1963).

18 I return to this example infra Part III.A.

19 See Gideon Parchomovsky \& Peter Siegelman, Selling Mayberry: Communities and Individuals in Law and Economics, 92 CALIF. L. REV. 75, 77 (2004).

20 Id. at 79. 
has their challenge to the discipline's individualistic focus been acknowledged, let alone engaged. ${ }^{21}$

To begin to untie this Gordian Knot in the thinking of law and economics, Part I describes ambiguities in the economic discourse of methodological individualism, and suggests how we might understand its invocation in law and economics. Part II highlights the ways in which a single-minded emphasis on individuals constitutes a flawed approach to questions of great interest to legal scholars, including social norms, network externalities, coordination games, and aspects of information economics.

In each case, I suggest, a methodologically individualist approach leads law and economics to overlook the dynamic of interdependence that is at work, and thereby distorts both the normative and positive conclusions we derive. To highlight as much, Part III reviews a handful of such distortions, including law and economics' faulty equation of consent with efficiency, its inadequate attention to evolution and change, and its flawed approach to the regulation of knowledge and information and to the management of financial crises.

\section{The MEANing(s) OF METHODOLOGICAL INDIVIDUALISM}

Law and economics - a sub-discipline of neoclassical economics - stands upon a pair of critical principles borrowed from the latter. ${ }^{22}$ As Robert Ellickson succinctly puts it: "The core of [the law and economics] paradigm was borrowed from economics. It consists of methodological individualism (the assumption that individuals are the only agents of human action) and the assumption that individuals are self-regarding and rational.".23

The limitations of the rationality assumption, of course, have been the subject of a rich literature in recent decades. ${ }^{24}$ Psychologists Daniel

${ }^{21}$ A similar example might be the work of George Akerlof and Rachel Kranton on what they have termed "identity economics." See, e.g., GeORGE A. AKerlof \& RACHEL E. KRANTON, IDENTITY ECONOMICS: How OUR IDENTITIES SHAPE OUR WORK, WageS, AND Well-BeING 6 (2010); George A. Akerlof \& Rachel E. Kranton, Economics and Identity, 115 Q.J. ECON. 715, $715(2000)$. They have argued over the last decade that a proper calculation of individual utility requires integration of relevant social categories, attendant norms, and the potentially substantial consequences of conformity with (or deviation from) those norms. Significant implications follow for the regulation of labor and employment, corporate governance, discrimination law, and the financing of public and private education - all issues of central importance in the study of law. With the exception of a handful of relevant scholars, however, their work has gone unexplored in the law and economics literature.

22 See Robert CoOter \& Thomas Ulen, LAw and Economics 15-52 (1988); Ron Harris, The Uses of History in Law and Economics, 4 THEORETICAL INQ. L. 659, 666 (2003).

${ }^{23}$ Ellickson, supra note 2, at 539; see also Christian Kirchner, The Difficult Reception of Law and Economics in Germany, 11 INT'L REV. L. \& ECON. 277, 283 (1991); McChesney, supra note 8, at 295.

${ }^{24}$ As careful commentators have highlighted, the rationality assumption - properly understood - is far more modest than its critics would like to suggest. See Russell 
Kahneman and Amos Tversky, and economists including Herbert Simon, jointly laid the foundations for this critique. ${ }^{25}$ Legal scholars, however, have since picked up - and significantly advanced - the ball of behavioral analysis. ${ }^{26}$ Bald assertions of rationality are, as a result, far less common in the law and economics literature than they used to be.

By contrast, the second principle borrowed from neoclassical economics methodological individualism - has been analyzed far less critically by students of law and economics. ${ }^{27}$ In the sub-sections that follow, I begin with a brief review of the historical origins of methodological individualism. I then consider the tendency to insert questions of what ought to be and what is the place of individuals into invocations of methodological individualism - a concept properly understood to speak only to how we analyze relevant social, economic, and political phenomena. I conclude by suggesting that those who invoke methodological individualism may wish to have their cake and eat it too - acknowledging, and even analyzing, social and institutional factors, but inappropriately marginalizing their role in the analysis.

\section{A. The Origins of Methodological Individualism}

In its earliest origins, the term "methodological individualism" has been traced to the work of Joseph Schumpeter, in 1908. ${ }^{28}$ As Schumpeter defined it, however, its meaning was far narrower than what we commonly intend by it today. Schumpeter's argument was simply that the economist "starts from the individual in order to describe certain economic relationships." 29 He rejected, by contrast, the practice of what he termed "sociological individualism" essentially what we have since embraced under the rubric of methodological individualism. In this flawed analytical approach, "the self-governing individual constitutes the ultimate unit of the social sciences; and . . . all social

Korobkin, A Multi-Disciplinary Approach to Legal Scholarship: Economics, Behavioral Economics, and Evolutionary Psychology, 41 JURIMETRICS J. 319, $321-22$ (2001); Tanina Rostain, Educating Homo Economicus: Cautionary Notes on the New Behavioral Law and Economics Movement, 34 LAW \& SoC'Y REV. 973, 977 (2000).

${ }^{25}$ See supra notes 4-5 and accompanying text.

${ }^{26}$ See sources cited supra note 6.

${ }^{27}$ Cf. AKerlof \& KRANTON, supra note 21, at 113 (proposing to "modify and broaden economic analysis to include identity").

${ }^{28}$ See Joseph Schumpeter, On the Concept of Social Value, 23 Q.J. ECON. 213, 231 (1909) (citing JOSEPH SCHUMPETER, DAS WESEN UND DER HAUPTINHALT DER THEORETISCHEN NATIONALÖKONOMIE [THE NATURE AND ESSENCE OF ECONOMIC THEORY] 91 (1908)); see also Hovenkamp, supra note 13, at 33; Lars Udehn, The Changing Face of Methodological Individualism, 28 ANN. REV. Soc. 479, 484 (2002).

${ }^{29}$ Panayotis G. Michaelides \& John G. Milios, Joseph Schumpeter and the German Historical School, 33 CAMBRIDGE J. ECON. 495, 502 n.3 (2009) (quoting SCHUMPETER, supra note 28, at 91). 
phenomena resolve themselves into decisions and actions of individuals that need not or cannot be further analyzed in terms of superindividual factors." 30

Before Schumpeter, notions of methodological individualism can likewise be seen in the literature of the Austrian School of Economics - best known to us through the work of Friedrich Hayek, but initially founded on Carl Manger's "atomistic method" and Ludwig von Mises' additions thereto., Mises thus cast the methods of economic analysis as exclusively individualistic: "If we scrutinize the meaning of the various actions performed by individuals we must necessarily learn everything about the actions of collective wholes." 32

The intent of the Austrian School, however, was not to deny the importance of institutions or to render groups irrelevant. Rather, the School hoped to more fully and properly explain collective entities by way of individual actions. Their project was, in a sense, a version of neoclassical economics' effort to explain prices in purely individual terms. ${ }^{33}$ Austrian economics ultimately moved away from a rigid individualism, moreover, as in evident in the work of Hayek himself. As he states in one of his later works:

The overall order of actions in a group is in two respects more than the totality of regularities observable in the actions of the individuals and cannot be wholly reduced to them. It is so not only in the trivial sense in which the whole is more than the mere sum of its parts but presupposes also that these elements are related to each other in a particular manner. It is more also because the existence of those relations which are essential for the existence of the whole cannot be accounted for wholly by the interaction of the parts but only by their interaction with an outside world both of the individual parts and the whole. ${ }^{34}$

It was during the Twentieth Century, however, that the rhetoric of methodological individualism became more widespread. ${ }^{35}$ Standard use of the term thus arose out of conflicts between economists and sociologists - defined in significant part by their contrasting choice of method. ${ }^{36}$ While sociology

30 JOSEPH A. SCHUMPETER, HISTORY OF ECONOMIC ANALYSIS 888 (1954).

31 See Udehn, supra note 28 , at 484,486 . Other strands of the concept might be traced to the work of Jeremy Bentham, John Locke, and John Stuart Mill, among other nineteenth century sources. See $i d$. at 480,482 .

32 MisEs, supra note 17 , at 42.

33 See Udehn, supra note 28 , at 484.

34 F.A. HAYEK, Notes on the Evolution of Systems of Rules of Conduct, in STUDIES IN Philosophy, Politics AND Economics 66, 70-71 (1967); see also Marc Amstutz, Global (Non-)Law: The Perspective of Evolutionary Jurisprudence, 9 GERMAN L.J. 465, 468-69 (2008); cf. Christopher T. Wonnell, Contract Law and the Austrian School of Economics, 54 FORDHAM L. REV. 507, 523 (1986).

35 See Hodgson, supra note 9, at 212.

36 See Kenneth G. Dau-Schmidt, Economics and Sociology: The Prospects for an Interdisciplinary Discourse on Law, 1997 WIS. L. REV. 389, 392-93. 
thus embraced a methodological holism, in which collectives such as states, ethnic groups, classes, and the like were anthropomorphized for purposes of analysis, economics held itself out as the only true social science, by virtue of its methodological individualism. ${ }^{37}$

Economics thus came to be defined by the idea that the "individual is the irreducible unit of positive economic analysis" - an approach in which individual behaviors are the "only possible[] objects of social scientific study." 38 As Kenneth Arrow succinctly puts it, "each individual makes decisions to consume different commodities, to work at one job or another, to choose production methods, to save, and to invest." 39 Methodological individualists assume that these individual decisions, in turn, form "a complete set of explanatory variables." 40

In a methodologically individualist approach, thus, analysis of the social must occur by way of the individual. ${ }^{41}$ As Lars Udehn forcefully puts it in reviewing our varied definitions of methodological individualism, "no economic explanation is considered successful until all exogenous variables have been reduced to psychological states of individuals and natural constraints. Social institutions may appear in the models of neoclassical economics, but only as endogenous variables." 42

37 See id.

38 See Lawson, supra note 10, at 58, 59 (emphasis omitted); see also Dau-Schmidt, supra note 36, at 395 (asserting that the individual is the "dominant unit of analysis in economics"). James Buchanan offers a characteristically strong statement of the principle: "Those who prefer to conduct inquiry into the relationships among classes, states, and other organizations as such, and without attempts to reduce analysis to the individuals who participate, do not, in my view, pass muster as social scientists in any useful sense of the term." James M. BuChanan, EXPloRAtions into Constitutional ECONOMiCs 47 (1989).

39 Arrow, supra note 1 , at 1.

$40 \mathrm{Id}$. Beyond its core emphasis on the individual as the necessary unit of analysis, methodological individualism is often also linked to two cognate principles: the Schumpeterian conception of preference formation as exogenous to economic analysis, see Dau-Schmidt, supra note 36, at 396, 401-02, and the notion of the subjectivity of preferences, see Crawford, supra note 9, at 507-08 (describing the link between methodological individualism and the prohibition on "interpersonal utility comparisons"); Herbert Hovenkamp, Knowledge About Welfare: Legal Realism and the Separation of Law and Economics, 84 MINN. L. REV. 805, 841 (2000). I return to the implications of these cognate principles infra Part I.C.

41 "Social phenomena should be explained in terms of individuals, their physical and psychic states, actions, interaction, social situation and physical environment." Udehn, supra note 28, at 499 fig. 2 ; see also Crawford, supra note 9, at 507 ("The only way to a cognition of collectives is the analysis of the conduct of its members." (quoting LUDWIG von Mises, Human Action: A Treatise on Economics 42 (Henry Regnery Co. 1966) (1949))); cf. Edward L. Rubin, Putting Rational Actors in Their Place: Economics and Phenomenology, 51 VAND. L. REV. 1705, 1713 (1998) ("[S]ocial structures arise from the behavior of individual human beings and are best explained in terms of that behavior.").

42 Udehn, supra note 28 , at 483. 


\section{B. Individualism as Ought, Is, and How}

Now common references to methodological individualism in both the economics and the law and economics literatures, however, continue to leave a great deal to the imagination. ${ }^{43}$ Most foundationally, there is significant ambiguity as to relevant authors' intent to capture distinct normative, ontological, and/or methodological claims. Even where reference is made to methodological individualism, thus, other claims are often intended.

Quite commonly, to begin, assertions of methodological individualism turn out to be grounded in some normative claim of individualism. In the work of James Buchanan, Hayek, and others, much of the motivation behind an individualistic method is the perceived need for robust individualism in the design of a moral, sustainable, or efficient social order. ${ }^{44}$ In these cases, the intertwining of "methodology and ideology" is by design. ${ }^{45}$ At least as often, however, such ambiguity may arise because the line between normative and methodological claims is difficult to draw. ${ }^{46}$

Ontological claims of individualism likewise stand behind many references to methodological individualism. As Margaret Thatcher famously put it: "There is no such thing as society. . . . There are individual men and women, and there are families." 47 Here, the claim is still not one of method, but neither is it normative. Instead, it is an ontological statement of the state of reality. Individuals, the claim goes, are the basic units of the social and economic order. As such, they are the necessary decision-makers and actors as to any relevant question. ${ }^{48}$

Methodological individualism, by contrast, requires no normative embrace of individualism, nor even any ontological conclusion as to the actual place of the individual in the social and economic order. ${ }^{49}$ Rather, it simply suggests

43 " [W] are dealing with one of those plastic words which mean very different things to different people; even for the same person, its meaning varies according to context. Indeed, I would attribute much of the hold that individualism has on the modern mind to a confusion of meanings." MARGLIN, supra note 15, at 58.

44 See Arrow, supra note 1, at 1. It bears emphasizing that nothing herein is inconsistent with a strong normative commitment to individualism.

$45 \mathrm{Id}$.

46 See id.; Hodgson, supra note 9, at 213.

47 The Collected Speeches of Margaret Thatcher 576 n.1 (Robin Harris ed., 1997) (quoting Interview by WOMAN's OWN with Margaret Thatcher, Prime Minister, United Kingdom (Oct. 31, 1987)).

48 This meaning of "methodological" individualism may be what Elster famously characterized as "trivially true." See ELSTER, supra note 10, at 13. It is likewise the concept at work in Amartya Sen's embrace of individualism as "a manifest reality in the world." AMARTYA SEN, THE IDEA OF JUSTICE 245 (2009). Some have also seen in Sen's capability approach, however, an ethical or normative individualism. See Ingrid Robeyns, Sen's Capability Approach and Feminist Concerns, in THE CAPABILITY APPROACH: CONCEPTS, MEASURES AND APPLICATIONS (Flavio Comim et al. eds. 2008).

49 Because my emphasis herein is the use of individualism as method, I do not attempt to 
that as a matter of social scientific method, the correct approach to explanation is to focus on the individual as the operative unit of analysis. Within this approach, talk of collectives - groups, networks, communities, and the like has no place. It can largely be dismissed as loose talk. At very best, it might serve to capture some aggregation of individual preferences and choices. As Larry Summers has put it: "It is the basis of much economic analysis that the good is an aggregation of many individuals' assessments of their own wellbeing, and not something that can be assessed apart from individual judgments on the basis of some overarching or separate theory." 50 For the methodological individualist, then, explanation must be reduced to individuals. ${ }^{51}$

The contribution of the foundational principle of methodological individualism to law and economics, then, is properly understood to be about method - not the various normative or ontological claims that are often advanced in its shadow. Even after we recognize as much, however, significant ambiguity remains as to what it means for law and economics to be methodologically individualist.

\section{Individuals and Institutions in Explanations}

What does it mean, thus, to reduce explanations to individuals? In trying to navigate this question, those who embrace methodological individualism wind up between Scylla and Charybdis. ${ }^{52}$ As Geoffrey Hodgson suggests, two possibilities would seem to present themselves: either explanations must be reduced to individuals alone, or they must embrace individuals and their interactions - essentially, individuals and institutions. ${ }^{53}$

The first possibility is problematic on its face. As Hodgson points out, meaningful explanation of social and economic phenomena is likely to be impossible without some acknowledgement of interaction and institutions. ${ }^{54}$ This would seem especially true of the legal analysis in law and economics.

offer a positive theory of the role of groups in social ordering. Among the seminal efforts in that vein, however, is Sober and Wilson's work on group selection in evolutionary biology. See Elliott Sober \& David Sloan Wilson, Unto Others: The Evolution and PSYCHOLOGY OF UNSELFISH BEHAVIOR 4-7 (1998).

50 MARGLIN, supra note 15, at 63 (quoting Summers).

st See Jon Elster, Marxism, Functionalism, and Game Theory: The Case for Methodological Individualism, 11 THEORY \& SOC'Y 453, 453 (1982) (defining methodological individualism as "the doctrine that all social phenomena (their structure and their change) are in principle explicable only in terms of individuals - their properties, goals, and beliefs"). Under this approach, "[t]he individual, along with his or her assumed behavioral characteristics, is taken as the elemental building block in the theory of the social or economic system." Geoffrey M. Hodgson, Hayek, Evolution, and Spontaneous Order, in Natural Images in Economic Thought: "Markets ReAd IN TOOTh and Claw" 408, 410 (Philip Mirowski ed., 1994).

52 See John H. FinLeY, JR., HOMER's OdYSSEY 131-38 (1978).

53 See Hodgson, supra note 9, at 215-16.

${ }^{54}$ See id. 
Given the institutional orientation of law, the extreme reductionism of an explanation grounded in individuals alone would seem entirely out of place.

The second possibility, on the other hand, would seem to concede too much. If both individuals and their interactions - and hence social dynamics, institutions, and the like - are part of the explanation, there is nothing especially individualistic about the latter. We might equally cast the mandate as methodological institutionalism, or at least as what Joseph Agassi has termed "institutional individualism." 55

In responding to this dilemma, students of law and economics might be seen as trying to have their cake and eat it too. Social factors - interactions and resulting institutions - are acknowledged, and even analyzed, but they are placed at the margins in the actual explanation of observed states of the world. ${ }^{56}$ By way of two cognate principles of methodological individualism, thus, its practitioners have respectively sought to exogenize or endogenize social and institutional factors. Either way, we get to the same result: these factors wind up at the margins, rather than at the heart, of the analysis.

The first cognate principle of methodological individualism is thus the view that the formation of preferences is exogenous to the analysis. ${ }^{57}$ Given this position, the role of social and institutional factors as determinants of preferences can simply be put aside. Such questions are thereby placed beyond the scope of standard economic - and hence law and economics - analysis. ${ }^{58}$ As we will see, however, this approach often proves problematic. It is unsustainable, for example, where the exogenized factors are so obviously central that their absence renders the analysis vacuous.

Where the exogenization of social and institutional factors cannot be sustained, a second principle of methodological individualism kicks in: the subjectivity of preferences. ${ }^{59}$ The latter, in practice, is simply another means to the same end. According to the principle of subjective preferences, any preference can be reconciled with rationality analysis, and hence must be accepted within a methodologically individualist approach. Anything, basically, can be endogenized into an individual's utility function. ${ }^{60}$ This second principle thus creates a kind of dumping ground for difficult or

\footnotetext{
55 See id. at 220-22; Udehn, supra note 28, at 489.

${ }^{56}$ Such states are what I will refer to, in the context of Coleman's famous diagrams, as the "social outcomes" of interest. See infra notes 62-63 and accompanying text.

57 See Dau-Schmidt, supra note 36, at 396, 401-02.

58 See supra note 41 . In a sense, one might think of the question as one of what data to consider. See Hovenkamp, supra note 40, at 842-43. Methodological individualism looks to a narrower set of data than I would suggest is appropriate for the meaningful analysis of social norms, network externalities, and the other phenomena explored infra Part II.

59 See Crawford, supra note 9, at 507-08; Hovenkamp, supra note 40, at 841 .

${ }^{60}$ See Udehn, supra note 28, at 500 ("[M] any economists cherish the dream of being able to endogenize all institutions.").
} 
problematic elements of the analysis - including social and institutional factors that might otherwise loom large in our evaluation. ${ }^{61}$

By way of such endogenization, thus, the methodological individualist effectively downgrades the place of social and institutional factors in her analysis. Such elements are not part of the explanation; they are not evaluated as causes. No longer, in this approach, are social and institutional factors direct determinants of observed results. At best, they become indirect causes, through their impact on the individual preferences that the analysis sees to dictate our actual choices. ${ }^{62}$

To appreciate what these twin principles exclude from the analysis, a slightly modified depiction of the so-called Coleman diagram - which sociologist James Coleman developed to suggest a middle ground between the methodological individualism of economics and the methodological holism of sociology - may be useful.

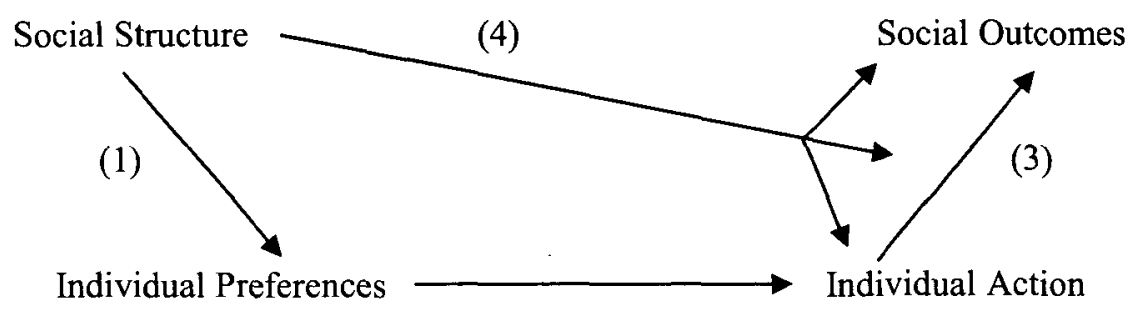

(2)

Capturing the narrowest form of methodological individualism, Coleman's framework depicts individual action as generated by individual values and preferences (2), and grounds social outcomes in the actions of individuals (3). It further recognizes the aforementioned endogenization of social and institutional factors, in its linkage of individual values and preferences to social structure (1). ${ }^{63}$

Beyond the foregoing, however, Coleman's schema also recognizes that social structure not only shapes individual preferences, but likewise provides the context and framework within which individual actions interact - and may

61 As with the attempt to exogenize social and institutional factors, endogenization of the latter has its limits. Whenever we push too much into an individual's utility function, it begins to look incoherent. See MARGLIN, supra note 15, at 65-66. This is particularly so, however, when the relevant additions are of a social, institutional, or altruistic nature. Individual utility thus looks a great deal less individual, when it consists of preferences that are so explicitly social in their construction. Id.

62 If methodological individualists do consider social factors to be part of the explanation, conversely, it becomes difficult to know what it means to be a methodological individualist. At a minimum, the line between methodological individualism and holism begins to seem quite blurred. See Udehn, supra note 28, at 500 .

63 See id. at 493-94. 
thus shape social outcomes more directly as well (4). Social structure "takes the form of a set of interdependent positions that are prior to the interaction between the individuals occupying these positions." 64 Contrary to the dictates of methodological individualism, therefore, "talk about 'aggregation' is misleading: "for the phenomena to be explained involve interdependence of individuals' actions, not merely aggregated individual behavior."'65

Where it attempts to exogenize preference formation - whether by social and institutional factors or otherwise - methodological individualism paints the formation of individual preferences by social structures (i.e., the first axis) as beyond the scope of relevant analysis. Where it endogenizes social and institutional variables, in turn, it seeks to deny the direct effects - along the fourth axis of Coleman's diagram - of social structure on social outcomes.

In a methodologically individualist approach, as a result, the constraints of interest are not social and institutional ones. Rather, they are the more tangible limits of budgets, income, and the like. As Dau-Schmidt notes, "when economists talk about constrained choices they are focusing on how scarcity and people's budgets affect their choices rather than how culture might influence what people choose within the confines of their budget."66 Contrast this limited perspective with the more institutional approach described by Karl Popper: "I propose to use the name 'social institution' for all those things which set limits or create obstacles to our movements and actions almost as if they were physical bodies or obstacles. Social institutions," he counseled, "are experienced by us as almost literally forming part of the furniture of our habitat."67

In the methodological individualism of law and economics, when culture as well as social dynamics and institutions more generally - appear, they do not function as constraints of direct interest to the analysis, but at best, as indirect influences on individual values and preferences. As we shall see, however, this approach offers a poor window into important areas of legal and economic analysis. In these areas, it is essential to go beyond an individualistic focus, and engage the place of social and institutional factors as direct causes, and not merely indirect influences, in the explanation of social and economic phenomena.

${ }^{64} \mathrm{Id}$. at 494. Akerlof and Kranton see "identity" in just this light. See AKERLOF \& KRANTON, supra note 21, at 10-11.

${ }^{65}$ Udehn, supra note 28 , at 494 (emphasis added) (quoting JAMES S. COLEMAN, FOUNDATIONS OF SOCIAL THEORY 22 (1990)).

66 Dau-Schmidt, supra note 36, at 401 n.77.

${ }^{67}$ Karl R. Popper, The Myth of the Framework: In Defence of SCIENCE ANd RATIONALITY 167 (M.A. Notturno ed., 1994). Akerlof and Kranton draw a further point of distinction, which may be relevant here as well. They distinguish between "[g]arden-variety tastes" - for apples versus oranges, for example - and identities and norms that derive from one's social setting. See AKERLOF \& KRANTON, supra note 21, at 6, 84 . 


\section{THE LIMITS OF METHODOLOGICAL INDIVIDUALISM}

[T] he foundational assumptions of economics . . . limit the ability of economists to understand the parts of the world in which we must perforce take an interest. An economist need not care about community, but it is harder to avoid such issues as the determinants of saving and investment, or the role of the distribution of income in assessing economic outcomes, or even in addressing the question of why markets are good for people. In all of these areas, the foundations of the discipline not only undermine community; they undermine economic analysis.

\section{- Stephen A. Marglin 68}

The methodological individualism of the law and economics literature, as we have seen, encourages a strong orientation to individuals as the focus of explanation. While social dynamics and institutions are acknowledged, and even analyzed, they are not evaluated as direct causes. At best, they may help to explain individual preferences, which are emphasized as the operative predictor of individual action and, in turn, of social outcomes.

In important areas of law and economics analysis, however, this approach proves faulty - at least minimizing the insight we can gain, if not leading us astray. Before turning to these areas, however, it is useful to acknowledge an even broader tension between the economics literature today, and the methodological individualism of law and economics.

Some conflict within methodological individualism might thus be found in the very framework of modern economic analysis - general equilibrium theory. Most commonly, equilibrium theory has been cast as the paradigmatic expression of methodological individualism. Lars Udehn, for example, has emphasized the strong individualistic rhetoric of Kenneth Arrow - the preeminent economic theorist of equilibrium. ${ }^{69}$

It is especially notable, thus, to recall Arrow's 1994 address to the American Economic Association - a passage of which I highlighted at the outset. ${ }^{70}$ In that address, Arrow challenged his fellow economists' persistent commitment to methodological individualism, objecting that "every economic model one can think of includes irreducibly social principles and concepts." "7l Contrary to Udehn, moreover, Arrow argued that general equilibrium theory itself should be understood as social in nature. Minimally, prices can be understood as social because they are chosen on the market and not by individuals. More broadly, the very concept of the market - particularly in its function as a resource-allocation mechanism - might be cast as inconsistent with

\footnotetext{
68 MARGLIN, supra note 15 , at 4.

69 See Udehn, supra note 28 , at 482-83.

70 See supra note 1 and accompanying text.

71 Arrow, supra note 1, at 2.
} 
methodological individualism: "Tastes may be socially caused; expectations are influenced by others; firms are organizations," and the like. ${ }^{72}$

Beyond any such broad tension, however, it is useful to note a number of areas in which a method that marginalizes social and institutional factors, whether by their exogenization or their endogenization, is not likely to generate meaningful insight. In this section, I highlight four areas in particular: social norms, network externalities, coordination games, and knowledge and information. Across each of these spheres, I ultimately conclude, a common strand of interdependence undermines the benefits of a methodologically individualist approach. ${ }^{73}$

\section{A. Social Norms}

Perhaps the most important area of conflict with methodological individualism in law and economics is the study of social norms. ${ }^{74}$ In recent years, social norms have been a subject of growing interest among students of philosophy, psychology, sociology, economics, and law. In law and economics, their study has been shaped by a characteristic methodological individualism. ${ }^{75}$ This hardly seems a natural fit, however, given social norms' obvious emphasis on the social. ${ }^{76}$

72 Id. at 4 . The very discussion of externalities, Arrow suggests, might be seen to conflict with the practice of methodological individualism. See id. at 5-6. Others have also highlighted tensions between economic theory and methodological individualism, including an inability to define "goods" absent some social construction, see Paul N. Cox, The Public, The Private and the Corporation, 80 MARQ. L. REV. 391, 429-30 (1997), or even to engage in the exercise of welfare economics, see Crawford, supra note 9, at 513.

${ }^{73}$ Beyond the study of social norms, network externalities, coordination games, and knowledge and information, other literatures may also conflict with a continued insistence on methodological individualism. These potential conflicts include at least the historical strand of institutional economics exemplified by the work of Douglass North, see, e.g. Douglass North, Economic Performance Through Time, 84 AM. ECON. REV. 359, 360 (1994), if not also the transaction-cost strand of Oliver Williamson, see, e.g., Oliver E. Williamson, Transaction-Cost Economics: The Governance of Contractual Relations, 22 J.L. \& ECON 233, 233-34 (1979). Recent work in search theory and Elinor Ostrom's analysis of common pool resources may also fall into this category, as might certain strands of the social psychology and organizational theory literature.

${ }^{74}$ See, e.g., Robert C. Ellickson, Order Without law: How Neighbors Settle DISPUTES 123 (1991) (offering a theory "designed to illuminate in what social context and with what content informal norms emerge to help people achieve order without law"); ERIC A. PoSner, LAW AND SOCIAL NoRmS 3 (2000); Bernstein, supra note 12, at 1725 (highlighting the role of norms within the cotton industry's private legal system).

75 See Susan D. Carle, Theorizing Agency, 55 AM. U. L. REV. 307, 319 (2005); Ellickson, supra note 2, at 539 . Methodological individualism characterizes even much of the noneconomic social norms literature. See, e.g., Cristina Bicchieri, The Grammar of SOCIETY: THE NATURE AND DYNAMICS OF SOCIAL NORMS 22 (2006).

${ }^{76}$ See, e.g., Ellickson, supra note 2, at 343-44. 
The social norms literature has, to a significant degree, been oriented to the role of social norms as substitutes for law. The operation of social norms, however, involves a fundamentally different dynamic from that of law. While students of social norms have identified a variety of ways in which social norms might exert influence - from internalization to shaming and other species of third-party enforcement - all share a common distinction with legal enforcement: the efficacy of a social norm depends, at its foundation, on a perception of it being embraced broadly. ${ }^{77}$ A social norm is only so because it is seen to be so. ${ }^{78}$

As a consequence, community matters critically to social norms. The social norms literature's various frameworks of norm compliance - from firstthrough third-party accounts - all require some baseline community structure out of which the given mechanism of compliance may arise. Some extant social framework, as such, must precede the operation of social norms.

Given as much, a distinct emphasis on individualistic analysis is hard to reconcile with the analysis of social norms. The whole discussion of social norms goes to social and community dynamics. The interesting question is not only why individuals comply with norms, but what causes norms to emerge, to evolve, and to persist or be abandoned. Our attention in the study of social norms thus seems most appropriately directed to the relevant social dynamics themselves, and to the social conceptions they engender.

Social norms are further distinct from law in that social norms serve a broader set of functions than the latter. In primary part, law serves to solve collective action problems. As Edna Ullmann-Margalit points out, however, social norms also do other, more social and community-oriented things. ${ }^{79}$ Specifically, they may be important in addressing coordination problems, as well as distributional and equity concerns. ${ }^{80}$ Taking an individualistic approach to social norms necessarily downplays these contributions.

Recent work of George Akerlof and Rachel Kranton on the need to factor "identity" into economic analysis - to consider "the individual in the social setting" ${ }^{\prime \prime 1}$ - might also be cited in this regard, given their emphasis on norms. ${ }^{82}$

77 See BICCHIERI, supra note 75.

78 The point is even clearer when one considers the related dynamic of convention. See MARGLIN, supra note 15, at 148; see also DAVID K. LEWIS, CONVENTION: A PHILOSOPHICAL STUdy 97 (1969); EdNA UllmaNn-MARGalit, The EMERgENCE of NoRMS 76 (1977).

79 See UlLMANN-MARGAlit, supra note 78, at 134-37.

80 See id.

81 AKERLOF \& KRANTON, supra note 21, at 28.

82 See id. at 18-20, 28; see also Akerlof \& Kranton, supra note 21; George A. Akerlof \& Rachel E. Kranton, Identity and Schooling: Some Lessons for the Economics of Education, 40 J. ECON. LIT. 1167, 1167-68 (2002) (positing that school quality actually correlates to a student's identity in relation to the school's social settings); George A. Akerlof \& Rachel E. Kranton, Identity and the Economics of Organizations, J. ECON. PERSP., Winter 2005, at 9, 12 (describing an identity model that takes account of norms); George A. Akerlof \& Rachel E. Kranton, Identity, Supervision, and Work Groups, 98 AM. ECON. REV. 212, 212 (2008); 
Even as economists have come to engage more closely with the real world through their engagement with more realistic tastes, and subsequently through the insights of behavioral economics - Akerlof and Kranton argue they have continued to give inadequate attention to the social context and categories within which individuals define their utility. ${ }^{83}$ To be useful, they counsel, any attempt to specify individual utility must incorporate these categories and the norms that follow from them. ${ }^{84}$

It is hard to overstate the implications of this approach in important areas of legal analysis, including labor and employment, education, discrimination, and even corporate governance. Yet a strongly individualistic orientation necessarily minimizes the place of social categories, identities, and resulting norms in our analysis. While Akerlof and Kranton do not explicitly challenge methodological individualism, their emphasis on identity stands in significant tension with the persistent methodological individualism of law and economics.

In sum, methodological individualism operates to marginalize social norms. For many scholars of law and economics, social norms are functionally irrelevant, given the exogeneity of preference formation. ${ }^{85}$ Methodological individualism confines even those who attend to social norms, however, to an approach in which norms are endogenized into individual utility functions. ${ }^{86}$ As noted, this minimally reduces attention to other, at least equally important, functions of social norms. More significantly, an individualistic approach to social norms does not see them as constraints of the sort cognizable to law and economics. ${ }^{87}$ Such an approach thus fails to engage norms' potential direct causal effects - not simply their influence on individual preferences, but their shaping of the architecture of choice within which those preferences play out and interact. ${ }^{88}$

George A. Akerlof, Social Distance and Social Decisions, 65 ECONOMETrICA 1005, 1005 (1997) (discussing "social distance" as a factor for understanding decision making, given the fact that decisions are shaped by social factors and their effects on individuals); George A. Akerlof, The Missing Motivation in Macroeconomics, 97 AM. ECON. REV. 5, 6 (2007) (criticizing prior economic doctrine for failure to consider norms of decision makers).

83 See AKERLOF \& KRANTON, supra note 21, at 7.

${ }^{84}$ Akerlof and Kranton offer an approach that still begins with individual tastes, but then proceeds through a three-step process - associating individuals with relevant social categories, specifying the prevailing norms within those categories, and then positing individual gains and losses arising from particular decisions, given said categories and norms - to integrate identity as well. See id. at 14, 17-18.

${ }^{85}$ See supra Part I.C.

86 See id.

87 See supra note 62 and accompanying text.

88 See supra Part I.C; $c f$. RICHARd H. Thaler \& CASS R. SUNSTEIN, NuDgE: IMPROving Decisions about Health, Wealth, and Happiness 3 (2008) (defining the concept of "choice architecture"). 


\section{B. Network Externalities}

Beyond social norms, so-called network externalities are similarly ill-suited to individualistic analysis, and likewise familiar to law and economics scholars. $^{89}$ Such effects arise where the utility of a good to a consumer increases with its consumption by others. ${ }^{90}$ As to such network goods - the telephone and fax machine being among the most obvious examples - network size (i.e., the number of other users) very much matters. ${ }^{91}$

Where network externalities are present, the analysis of individual utility becomes difficult to separate out from the assessment of social utility. As with social norms, consequently, a distinctly individualistic methodology is prone to miss as much as it captures.

To appreciate as much, recall Joseph Schumpeter's original coining of the term "methodological individualism." 92 He concludes that:

Marginal utilities do not depend on what society as such has, but on what individual members have. Nobody values bread according to the quantity of it which is to be found in his country or in the world, but everybody measures the utility of it according to the amount that he has himself, and this in turn depends on his general means. ${ }^{93}$

In network settings, however, individuals value a good precisely according to "the quantity of it which is to be found in [their] country or in the world."

This point is obvious, of course, with regard to telephones, fax machines, and similar technologies. But we can see it in a far broader range of "networks" as well. Some network dynamic will often be present in efforts at technological innovation, and even in economic growth generally, given positive feedback loops arising from individual initiative in each regard. ${ }^{95}$ Similarly, Parchomovsky and Siegelman highlight the importance of networktype interactions in explaining the need for law and economics to attend to community: "[E]ach resident in a community has a stake in the continued presence of other members and simultaneously bestows a benefit on others by his own presence." 96 Most broadly, one might cast human social existence

89 See Robert B. Ahdieh, Law's Signal: A Cueing Theory of Law in Market Transition, 77 S. CAL. L. REV. 215, 223-26 (2004) (discussing network effects in securities markets); Michael L. Katz \& Carl Shapiro, Systems Competition and Network Effects, J. ECON. PERSP., Spring 1994, at 93, 105-06.

90 See Lemley \& McGowan, supra note 12, at 599.

91 See Ahdieh, supra note 89, at 223-26; Katz \& Shapiro, supra note 89, at 105-06. Thus, network externalities have occasionally been described as demand-side economies of scale. See Robert P. Merges \& Jeffrey M. Kuhn, An Estoppel Doctrine for Patented Standards, 97 CALIF. L. REV. 1, 5 n.21 (2009).

92 See supra note 30 and accompanying text.

93 Schumpeter, supra note 28, at 214.

94 Id.

95 See Arrow, supra note 1, at 7.

96 Parchomovsky \& Siegelman, supra note 19, at 114. 
generally as defined by network dynamics of a sort: "Human behavior is the product of various factors that together make up a dynamic field, in the sense that the state of any part of the field depends on every other part of the field."97

This is not to suggest that Schumpeter was wrong to suggest the absence of "social utility" in the abstract. ${ }^{98}$ Nor does this approach dictate an embrace of sociology's methodological holism, an approach in which social masses classes, races, and the like - are analyzed as determinative actors. ${ }^{99}$ It simply suggests that we cannot ignore collective - and interdependent - determinants of individual utility if we are to meaningfully engage questions of individual utility in network settings. The methodological individualism referenced by Schumpeter is necessarily less useful, then, where his baseline assumptions about individual utility functions do not hold true. ${ }^{100}$

With network externalities, as with social norms, one can see how methodological individualism's desire to endogenize social and institutional factors avoids the critique I offer. One might justify a methodologically individualistic approach in network settings, thus, by characterizing network externalities as simply inputs into the utility functions of relevant individuals. In the presence of network effects, a methodologically individualist approach sees network externalities, such as the consumption patterns of others, or predictions about future consumption, as factors to be endogenized into individual utility functions along with more standard inputs, including relevant individual tastes and preferences.

This response, however, is equally complete and unsatisfying. Such an account stretches the confines of individual utility too far, essentially equating individual utility with social utility where network externalities are present. To so completely socialize individual utility, however, undermines the exercise. Recall that the question herein is one of method. What analytical approach will yield the greatest insight? Given the distortion attendant to a wholesale endogenization of network externalities - or social norms - into individual utility functions, it seems unlikely to constitute an ideal methodological approach. ${ }^{101}$

\section{Coordination Games}

As with the study of social norms and network externalities, the growing interest of law and economics in coordination games is difficult to reconcile with a strongly individualistic approach. ${ }^{102}$ Viewed broadly, one might see

\footnotetext{
97 Rostain, supra note 24 , at 987.

98 See Hovenkamp, supra note 13, at 33 (identifying this suggestion in Schumpeter's views).

99 See supra note 11 and accompanying text.

100 See supra note 93 and accompanying text.

101 See supra notes 59-62 and accompanying text.

${ }^{102}$ See, e.g., Robert B. Ahdieh, The Visible Hand: Coordination Functions of the Regulatory State, 95 MINN. L. REV. 578, 580-81 (2010); Russell Korobkin, Inertia and
} 
tension between the prescriptions of methodological individualism and game theory analysis generally. Game theory is often cast as classically methodologically individualist, given its emphasis on individual strategy choices. ${ }^{103}$ The rules of any given game, however, are necessarily social in nature. ${ }^{104}$ Individuals must define and agree on the rules collectively.

Whatever the limits of a methodologically individualistic approach to game theory generally, these are particularly acute in so-called "coordination games." As Richard McAdams has highlighted, legal scholars' fascination with the Prisoner's Dilemma dwarfs their attention to other strands of game theory, including the important realm of coordination games. ${ }^{105}$ As McAdams compellingly demonstrates, however, coordination game dynamics are at least as applicable in areas of interest to legal scholars - from bargaining and international law, to standard-setting and property law. ${ }^{106}$

In these coordination settings, participants' critical aim is to coordinate their behavior. Each player's choice of strategy thus depends on the choice made by her counterparts. If you are going to go to one potential location, I will go there as well, and vice-versa if you go to the other. Whatever preference I may have between the choices, it is dwarfed by the payoffs attendant to getting to the same place - i.e., to coordinating our strategies. ${ }^{107}$

This is not to suggest that conflict is absent in coordination settings. The famous game of Chicken, in which two cars race toward each other to see who will swerve first, is a classic, if highly conflictual, coordination game. ${ }^{108}$ Rather than a lack of conflict, thus, the critical feature of coordination games in contrast to Prisoner's Dilemma games - is that the parties lack a dominant strategy: a strategy they will play regardless of the strategy chosen by their

Preference in Contract Negotiation: The Psychological Power of Default Rules and Form Terms, 51 VAND. L. REv. 1583, 1586 (1998); Richard H. McAdams, Beyond the Prisoners' Dilemma: Coordination, Game Theory, and Law, 82 S. CAL. L. REv. 209, 211 (2009).

103 See Arrow, supra note 1, at 4-5; see also SHAUN P. HARGREAVES HEAP \& YANIS VAROUfaKIS, GAME THEORY: A CRITICAL INTRODUCTION 33 (1995) (describing potential for the origin of structures to be obscured in game theory, given its distinctive attempt to separate out choice and structure); Udehn, supra note 28, at 483 . Evolutionary game theory is not to the contrary, given its emphasis on strategic choice rather than "changes in the rules of the game." See Arrow, supra note 1, at 3.

104 See Arrow, supra note 1, at 4-5; Udehn, supra note 28, at 495.

105 McAdams, supra note 102, at 216.

106 See id. at 236-54.

107 See Ahdieh, supra note 89, at 233-38.

108 The most familiar reference for the game of Chicken may be the dramatic scene in Rebel Without a Cause, when Jim (played by James Dean) and Buzz race toward a precipice. Buzz "wins" the game, but only by going off the cliff with his car. REBEL WiTHOUT A CAUSE (Warner Bros. Pictures 1955). A more recent example of Chicken on the big screen occurred in the Kevin Bacon classic, Footloose, when Bacon's character and his nemesis faced each other down on tractors. Footloose (Paramount Pictures 1984). 
counterpart. ${ }^{109}$ Instead, their strategies are interdependent, such that each one's choice depends on the other's. ${ }^{110}$

Because of this interdependence, there are "multiple equilibria" in coordination games: more than one set of choices from which neither player will deviate, absent a change in strategy by their counterpart as well. As a result, the solution to coordination games - and hence the determination and prediction of relevant social outcomes - does not lie in any single individual alone. An individualistic mode of analysis tells us little. Rather, as Richard McAdams points out, history and culture - the institutional context in which individual choices are made - are essential to effective analysis in coordination settings. ${ }^{111}$

That economists and scholars of law and economics have tended to resist the identification of such multiple equilibrium dynamics should consequently come as little surprise. The presence of multiple equilibria conflicts directly with an insistence on methodological individualism as the sine qua non of true social science. ${ }^{112}$ In multiple equilibrium settings, methodological individualism falls short.

This conflict highlights an even deeper tension between multiple equilibria and the self-identification of economics, as well as law and economics, as positive sciences directed to the project of prediction. ${ }^{113}$ Such prediction becomes all but impossible once we accept the necessary role of social and institutional factors in multiple equilibrium settings. ${ }^{114}$ As two students of game theory have summarized it:

[T] he recurring difficulty with the analysis of many games is that there are too many potential plausible outcomes [i.e., multiple equilibria, in game theoretic language]. There are a variety of disparate outcomes which are consistent with (Humean) individuals qua individuals interacting. Which one of a set of potential outcomes should we expect to materialise? We simply do not know. Such pluralism might seem a strength. On the other hand, however, it may be taken to signify that the

109 See Adrian Vermeule, Foreword: System Effects and the Constitution, 123 HARV. L. REv. 4, 49 (2009).

110 One might see the collective dynamic in shareholders' response to tender offers as suggestive of this pattern. See Parchomovsky \& Siegelman, supra note 19, at 119-20 (citing Lucian Arye Bebchuk, Toward Undistorted Choice and Equal Treatment in Corporate Takeovers, 98 HARV. L. Rev. 1693, 1696 (1985)).

111 See McAdams, supra note 102, at 231-33.

112 See supra notes 36-40 and accompanying text.

113 See ElLICKSON, supra note 74, at 158; $c f$. MARGLIN, supra note 15, at 9 ("Economics takes very much to heart the famous dictum of the nineteenth-century physicist Lord Kelvin that we know only what we can measure. Indeed, economics takes the dictum a step further, from epistemology to ontology: what we can't measure - entities like community - doesn't exist." (citation omitted)).

${ }^{114}$ See Rostain, supra note 24, at 986-87. 
selection of one historical outcome is not simply a matter of instrumentally rational individuals interacting. There must be something more to it outside the individuals' preferences, their constraints and their capacity to maximise utility. The question is: what? ${ }^{15}$

Economics, as well as law and economics, thus cease to be readily predictive in the presence of multiple equilibria. Minimally, the task of prediction becomes a far more complex exercise, given the social and institutional factors at work. ${ }^{116}$

An insistence on methodological individualism avoids these difficulties, of course, but at the cost of meaningful insight. The avoidance of uncertainty by an insistent focus on the individual thus condemns us to mistake or mischaracterize what is happening in important - and perhaps increasingly important - coordination settings. ${ }^{17}$ We do better, then, to put aside our rigid methodological individualism and embrace the uncertainty attendant to the presence of multiple equilibria, given the important windows it can open up. ${ }^{118}$

This is especially crucial given that the multiple equilibria and attendant uncertainty that arise in coordination settings are not limited to those circumstances. They are far more common phenomena, thus, than economists and scholars of law and economics have been willing to admit. Multiple equilibria may even characterize general equilibrium theory itself. ${ }^{119}$ A distinctly individualistic orientation to law and economics, as a result, may be highly misleading.

\section{Knowledge and Information}

The necessarily social dimensions of the analysis of coordination games suggest a fourth area of legal and economic analysis ill-suited to a methodologically individualist approach: the study of knowledge and information. ${ }^{120}$ Ultimately, the solution to coordination games lies in players' possession of a certain "common knowledge" - some shared set of priors about

\footnotetext{
115 HaRgreaves Heap \& VAROUfaKis, supra note 103, at 33 (emphasis added).

116 Rostain, supra note 24 , at $986-87$ (citations omitted).

117 Parchomovsky's and Siegelman's analysis is a case in point. See supra notes 18-20 and accompanying text. I suggest others in Ahdieh, supra note 102, at 580-81.

118 See Julie E. Cohen, Copyright and the Perfect Curve, 53 VAND. L. REv. 1799, $1817-$ 19 (2000).

119 See Alan Kirman, The Intrinsic Limits of Modern Economic Theory: The Emperor Has No Clothes, 99 ECON. J. 126, 127 (1989).

120 See, e.g., Frank Pasquale, Copyright in an Era of Information Overload: Toward the Privileging of Categorizers, 60 VAND. L. REV. 135, 140 (2007) (arguing that copyright law should look beyond individual infractions to the negative externalities created by copyright infringers); Lior Jacob Strahilevitz, Reputation Nation: Law in an Era of Ubiquitous Personal Information, 102 Nw. U. L. REv. 1667, 1671 (2008) (suggesting that information about individuals will impact interactions); see also Joseph E. Stiglitz, Information and the Change in the Paradigm in Economics, 92 AM. ECON. REv. 460, 461 (2002).
} 
the world, its occupants, and their likely behavior. ${ }^{121}$ It is through such common knowledge that players develop accurate expectations of one another, and thus coordinate their behavior successfully. ${ }^{122}$ By definition, however, such common knowledge is necessarily social in nature. ${ }^{123}$ An analysis of it oriented to individuals is therefore likely to be uninteresting, if not misleading.

Beyond the question of common knowledge in coordination settings, one can see the limits of an individualistic approach to knowledge and information in the aspiration to reduce uncertainty more generally. Ignorance - a lack of relevant information - can be addressed by way of "algorithmic knowledge": "the knowledge of a calculating, maximizing homo economicus." 124 To overcome ignorance, thus, we need simply to find and/or provide missing information. To address uncertainty, by contrast, algorithmic knowledge will not suffice. What is needed, instead, is experiential knowledge. ${ }^{125}$ As Stephen Marglin has suggested, "coping with uncertainty is . . predominantly a matter of experiential knowledge, and will remain so no matter how adept at climbing decision trees or manipulating subjective probabilities we might become."126 Experiential knowledge, however, is rooted in community. The transfer of knowledge by experience turns on the presence of relevant associations and the necessary context for transfer. ${ }^{127}$ The engagement of uncertainty, then, requires a social analysis.

The rise of prediction markets, as well as the related dynamic of efficient capital markets, can be understood in this light. ${ }^{128}$ These concrete manifestations of the so-called "wisdom of crowds"129 recognize the

121 See Ahdieh, supra note 89, at 256-57; Richard H. McAdams, The Expressive Power of Adjudication, 2005 U. ILl. L. REV. 1043, 1064 n.73 (citing MiCHAEL S. CHWE, RATIONAL RitUAL 25-26 (2001)).

122 See supra notes 107-111 and accompanying text.

${ }^{123}$ As Arrow points out, "common pools of knowledge" are inherently social in nature. See Arrow, supra note 1, at 1-2; see also MARGLIN, supra note 15, at 147.

124 See MARGLIN, supra note 15, at 128.

125 See id. at 148.

126 Id. at $146-47$.

127 See id. at 147; cf. Donald C. Langevoort, Organized Illusions: A Behavioral Theory of Why Corporations Mislead Stock Market Investors (and Cause Other Social Harms), 146 U. PA. L. REV. 101, 137 (1997).

128 See, e.g., Michael Abramowicz, Predictocracy: Market Mechanisms for Public and Private Decision Making ix-xv (2007); Cass R. Sunstein, Infotopia: How Many Minds Produce Knowledge 132-33 (2006); Ronald J. Gilson \& Reinier H. Kraakman, The Mechanisms of Market Efficiency, 70 VA. L. REV. 549, 552 (1984); Lior Jacob Strahilevitz, "How's My Driving?" For Everyone (And Everything?), 81 N.Y.U. L. REV. 1699, 1702 (2006) (exploring "the use of information aggregation technologies to deter, detect, and punish citizen misconduct").

129 See James Surowiecki, The Wisdom of Crowds: Why the Many ARe SMarter Than the FEw and How COllective Wisdom Shapes Business, ECONOMIES, Societies, AND NATIONS xiii-xiv (2004). 
necessarily collective nature of efforts to grapple with uncertainty. The dynamic in such settings is emphatically not individual. To the contrary, it reflects the nature of groups as more than the sum of their parts.

Ultimately, however, we can cast the limits of a methodologically individualist approach to knowledge and information even more broadly. Recall, once again, the striking dismissal of methodological individualism by Kenneth Arrow: "[E]very economic model one can think of includes irreducibly social principles and concepts." 130 The prime example of the necessarily social dimension of economic analysis that Arrow highlighted, it turns out, is knowledge and information. As he suggests, "the importance of technical information in the economy is an especially significant case of an irreducibly social category in the explanatory apparatus of economics." 131

Broadly, the transfer of knowledge is not individualistic. Rather, as Arrow quotes Thorstein Veblen, " $[t]$ he commonplace knowledge of ways and means, the accumulated experience of mankind, is still transmitted in and by the body of the community at large." 132 The same is true of the creation of new knowledge, to which Arrow suggests economists have not been sufficiently attentive, given its centrality to economic growth. ${ }^{133}$ As with the transfer of existing knowledge, the acquisition of new knowledge is, in primary part, social in nature. ${ }^{134}$ An individualistic approach to knowledge would thus seem ill-advised.

\section{E. Individualism and Interdependence in Economic Analysis}

Behind the dynamics at work in each of the areas above - social norms, network externalities, coordination games, and knowledge and information lies a common strand of interdependence. Kenneth Dau-Schmidt has highlighted the importance of this feature: "[I]t would seem important to take account of the fact that people are not always independent actors, but are members of groups, and that such membership can sometimes affect their actions. This fact seems particularly relevant in analysis of the regulation of group-based activity such as racial discrimination."135 In essence, the claim herein is that the breadth of such "group-based activity" is broader than we

130 Arrow, supra note 1 , at 2.

131 Id. at 1. Arrow thus identifies "socially held technical knowledge as a main determinant of economic activity in every economy." $I d$. at 6 (citing Thorstein Veblen, Professor Clark's Economics, 22 Q.J. ECON. 147 (1908), reprinted in THE PLACE OF SCIENCE IN MODERN CiVILISATION AND OTHER EsSAys 180-230 (1919)). This conclusion is increasingly true with each passing day. Modern industrialized economies are thus defined more and more by firms whose value lies in their information advantages. See id. at 8 .

132 Id. at 6 (quoting Veblen, supra note 131, at 186).

133 See id. at 6-7.

134 See id. at 7 . Ultimately, we might plausibly think of information as itself breeding information, with the centrality of an individualistic analysis necessarily reduced. See id.

135 Dau-Schmidt, supra note 36, at 419. 
have commonly assumed. Properly understood, the dynamics at work in the presence of social norms, in the operation of network externalities, in coordination game settings, and in the creation and transfer of knowledge and information, all come within this sphere. The critical question in evaluating the effectiveness of a methodologically individualist approach consequently becomes the relative importance of such interdependence in understanding a given social or economic setting.

As Lynne Dallas posits: "To the socioeconomist, interdependencies are part of the human condition .... Interdependencies exist throughout the economy . ..."136 Law and economics analysis largely overlooks such interdependency, however, by way of its methodological individualism. Stephen Marglin thus points to his fellow economists' preference for "a narrow definition of selfinterest - one in which self-interest is a focus on one's own self, where my perception of how I ought to act, how I ought to be, is completely independent of what anybody else in society is consuming or doing."137 Why the preference for this approach? Because "a focus on the self eliminates the web of interconnections associated with a broader notion of self-interest; that is, a narrow notion of self-interest eliminates a whole class of externalities that might rob markets of their Pareto optimal properties."138

It bears emphasizing, however, that the interdependency at work in the areas considered above is not one of some vague, sentimental sort. Rather, what we find in the presence of social norms, network externalities, and the like is what we might more formally characterize as a correlation across individual utilities - what Alan Kirman describes as similar, even collective, demand. ${ }^{139}$ The relevant dynamic is one of positive feedback effects, in which the strategic choices and consumption patterns of any given individual pull others in a similar - or at least in some particular - direction. ${ }^{140}$ Given as much, an individualistic methodology must necessarily prove more limited in understanding such situations.

An understanding of interdependence as highlighting the category of settings in which law and economics' reliance on methodological individualism is flawed also helps to emphasize the distinction between the present argument and more familiar behavioral critiques of law and economics.

136 Lynne L. Dallas, Law and Socioeconomics in Legal Education, 55 RUTGERs L. REV. 855,859 (2003).

137 MARGLIN, supra note 15 , at 66.

${ }^{138}$ Id. In a similar vein, see Akerlof and Kranton's discussion of the derivation of certain tastes from social context and identity. AKERLOF \& KRANTON, supra note 21, at 32-33.

139 See Kirman, supra note 119 , at 138.

140 In other terms, the settings reviewed above are characterized by "increasing returns," including learning effects, coordination dynamics, and self-reinforcing adaptive expectations. See W. Brian Arthur, Increasing Returns and Path DEPENDENCE IN the ECONOMY 112 (1994); DOUglass C. NORTH, Institutions, Institutional Change and ECONOMIC PERFORMANCE 94-97 (1990). 
Here, the critical question is not one of individual rationality or irrationality. Rather, it is the impact of individual choices - rational or otherwise - on others. Kirman captures as much in contrasting the behavioral work of Herbert Simon with his own critique of individualism in economic analysis:

Yet it should be noted that provided the basic model is one in which individuals react in the same continuous way to signals (prices) [Simon's account] is formally equivalent to the Arrow-Debreu model. Indeed, as will be shown below, unless it could be proved that individual behaviour of the type invoked by Simon imposes restrictions on the collective behaviour because it leads people to behave similarly, we are no further advanced. ${ }^{141}$

A critique of methodological individualism - and the attendant inattention to interdependence - in economics and law thus goes to the foundations of neoclassical economics and the law and economics built on it, even more so than behavioral critiques.

The argument herein endorses neither the view of classical law and economics that widespread individual rationality drowns out isolated cases of irrationality, nor the view of behavioral law and economics that widespread irrationality drowns out isolated cases of rationality. Rather, the point it seeks to emphasize is the presence of more systematic determinants of - and resulting continuities in - individual behavior than either approach ordinarily acknowledges. My argument thus highlights the need for a more contextual approach, in which individual preferences and utility functions are determinative in some cases - and hence the appropriate methodological focus - while group factors are the necessary determinant in others. In any given case, we must ask, how much does the relevant social context, institutional setting, and resulting interdependence matter in the shaping of individual action and social outcomes? ${ }^{142}$

Ultimately, then, " $[\mathrm{t}] \mathrm{he}$ idea that we should start at the level of the isolated individual is one which we may well have to abandon."143 The rote invocation and practice of methodological individualism in law and economics is unwarranted. Just as traditional assertions of rationality produced less nuanced, less accurate, and less interesting accounts of law and economics, a

\footnotetext{
141 Kirman, supra note 119, at 127.

142 As Kirman aptly concludes:
}

If we look back briefly to the result that underlies the whole problem expressed here it is clear that in the standard framework we have too much freedom in constructing individuals. The basic artifact employed is to find individuals each of whose demand behaviour is completely independent of the others. This independence of individuals' behaviour plays an essential role in the construction of economies generating arbitrary excess demand functions. As soon as it is removed the class of functions that can be generated is limited. Thus making individual behaviour dependent or similar may open the way to obtaining meaningful restrictions.

Id. at 137-38.

${ }^{143} \mathrm{Id}$. at 138 . 
conceptualization of individuals as the necessary focus of study in law and economics, including even in the evaluation of social norms, network externalities, coordination, knowledge and information, and other settings of interdependence, has the potential to greatly distort our analysis. In fact, as we will see in the following section, it often does just that. ${ }^{144}$

\section{THE CONSEQUENCES OF METHODOLOGICAL INDIVIDUALISM}

A methodologically individualist approach is ill-advised with regard to important aspects of legal and economic analysis. Minimally, these include the study of social norms, network externalities, coordination games, and knowledge and information. More broadly, one might consider settings characterized by multiple equilibria, by uncertainty, and by interdependence as ill-suited to an individualistic approach. At the extreme, one might even see analysis of the market, price formation, and equilibrium generally to conflict with a strongly individualistic orientation. What, then, are the consequences of the continued practice of methodological individualism in law and economics?

I have already hinted at some of the ways in which the methodological individualism of law and economics distorts our analysis. The tendency of social norms scholars to focus on their role as substitutes for law might be traced to this approach. ${ }^{145}$ The commitment to methodological individualism may likewise help explain legal scholars' relative inattention to coordination games, by comparison with the Prisoner's Dilemma. ${ }^{146}$

Closer examination of a handful of additional consequences of law and economics' persistent methodological individualism, however, may help to highlight the importance of the analysis herein. The ensuing discussion, of questions of consent, the study of evolution and change, and the regulation of information and financial markets, is far from an exclusive enumeration of the ways in which methodological individualism may distort our understanding of law and economics. Other implications might be cited as well. It is suggestive, however, of why it is crucial that we be more attentive to our practice of methodological individualism, and more selective in its use.

\section{A. Community and Consent}

To appreciate the consequences of the methodological individualism of the law and economics literature, one might begin with Gideon Parchomovsky and Peter Siegelman's article, Selling Mayberry: Communities and Individuals in Law and Economics, which analyzes the purchase of nearly the entire town of

\footnotetext{
144 Again, it bears emphasizing that the critique herein is directed exclusively to the question of method, to which methodological individualism is properly understood to speak, and not to the normative or ontological claims that are often attached to it. See supra Part I.B. In the settings described in the section just concluded, I argue, an individual-oriented approach to the analysis is ill-advised.

${ }^{145}$ See supra notes 76-79 and accompanying text.

146 See supra notes 105-106 and accompanying text.
} 
Cheshire, Ohio by American Electric Power Company, given the company's ongoing environmental degradation of the town. ${ }^{147}$ In the standard, individualistic account of such pollution externalities in the law and economics literature, they point out, such a buyout should have been difficult (if not impossible) to accomplish, given attendant transaction costs, as well as individual incentives to hold out. ${ }^{148}$ Yet the deal proceeded with little difficulty, and no evidence of holdouts.

In seeking to explain as much, Parchomovsky and Siegelman critique the traditional analysis of pollution externalities from a purely individualistic perspective. This approach, they argue, causes us to miss much of what is really going on:

Although the economic analysis of pollution has been enormously influential, in terms of both theory and policy, the analysis has been conducted entirely from a perspective of methodological individualism. That is, law and economics scholars see victims in pollution disputes as acting independently of each other, with no interdependencies and no sense of social embeddedness. Although we acknowledge that the . . assumption of atomistic individualism can be powerful and productive in many cases, we argue that it is a highly incomplete description of human behavior, one that can be misleading in some important settings. ${ }^{149}$

It is critical, Parchomovsky and Siegelman argue, for law and economics scholars to likewise attend to "community" - which they characterize in terms echoing the analysis herein. ${ }^{150}$ There was, they suggest, a "strong interdependence among the utility functions of residents of the village."151 Residents shared "an interest in a common asset." 152 Community thus emerges as "a kind of positive externality that can exercise a profound effect on the outcomes of economic transactions." 153

Disregarding the latter, the traditional, methodologically individualistic approach of law and economics "misses the essential jointness of decision making in environments characterized by strong interpersonal ties." 154 Once we allow ourselves to recognize the collective dynamic at work, by contrast, it proves fairly easy to buy out an entire town. It may even be too easy, in Parchomovsky and Siegelman's view. ${ }^{155}$ Jurisprudential adjustments in the regulation of such buyouts thus become necessary, including a distinct

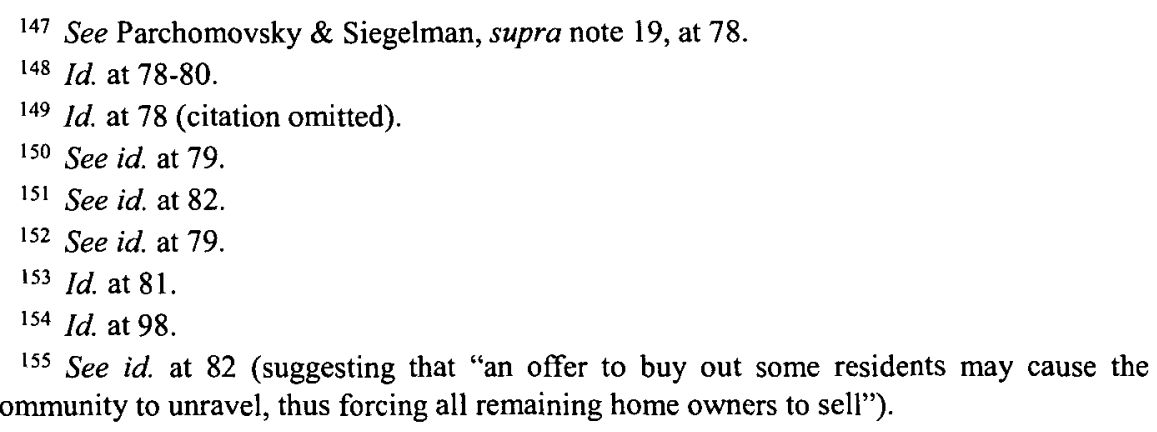


approach to evaluating the propriety of injunctive relief and greater care in assessing the possibility of under-compensation. ${ }^{156}$

Implications also follow for other areas of legal and economic analysis, including the dynamics of collective action and takings law. ${ }^{157}$ As to the latter, for example, attention to community highlights the inadequacy of existing jurisprudential categories of government takings. ${ }^{158}$ To avoid the potential for under-compensation, it is necessary to assess more critically the breadth of relevant exercises of eminent domain and their potential to generate "community externalities." 159 Depending on the latter, just compensation may be due even to property owners that a taking does not directly affect. ${ }^{160}$

Beyond these particular areas, the dynamic at work in Cheshire - and in cases where social norms, network effects, coordination dynamics, and knowledge and information play an important role - also highlights a broader point: it is essential for the law and economics literature to be far more cautious than its methodological individualism has commonly caused it to be in its analysis of individual consent.

Among individuals in Cheshire, as among those making the decision to observe a social norm, to purchase a technology compatible with a dominant network, to coordinate at a salient equilibrium, and the like, there is surely consent at the most basic level. There is no element, thus, of what we would think of as coercion. Consistent with ontological individualism, meanwhile, it is clear that individuals are the relevant decision-makers, not communities or a collectivity of some sort. ${ }^{161}$

What is less clear, on the other hand, is what we should understand this consent to signify. Minimally, our placement of normative weight on private contracting choices may be unwarranted in such settings. The consent manifest in Cheshire, in behavior consistent with prevailing social norms, and in consumer preferences for the dominant PC network, rather than the Apple alternative, thus may not constitute the robust signal that an individualistic law and economics commonly sees in it. ${ }^{162}$ That individuals choose to sell their homes in Cheshire or buy more PCs than Macs may not mean that those outcomes are efficient. In settings of interdependence, rather, even noncoerced choices may be more indicative of relevant social context than individual will. ${ }^{163}$

156 See id. at $126-27$.

157 See id. at $130-42$.

158 See id. at 137-38.

159 See id. at 136-37.

160 See id. at $134-39$.

161 See supra note 47 and accompanying text.

162 Stating the point differently, methodological individualism might be seen to encourage too strong an emphasis on markets as mediating institutions. See Dau-Schmidt, supra note 36 , at 395 .

${ }^{163}$ As Marglin puts it, we need to be more attentive to the sometimes obscure line 
More directly to the point herein, as a matter of methodology, it is unclear that indicia of consent are especially relevant to the analysis of settings of interdependence. In Cheshire, thus, what happened turned on the impact of community on individual residents' decisions to sell. The fact of individual consent, as such, tells us little.

Most explicitly, one might see this point as relevant to our notions of freedom of contract. In the setting of Cheshire, individuals chose to sell their homes, free of coercion. Given as much, their decisions can plausibly be cast as manifestations of the freedom of contract. Given the critical role of community in shaping those decisions, on the other hand, such an account would be woefully incomplete. Residents' nominal freedom of contract in Cheshire thus may not tell us nearly as much as we think.

Methodological individualism's distortion of our analyses of consent likewise implicate study of the firm. ${ }^{164}$ Absent a rigidly individualistic approach, one might more readily question contractarian notions of the firm. ${ }^{165}$ Minimally, though, a more complex account of consent would challenge the normative claims of efficiency that a nexus of contracts approach posits. ${ }^{166}$ This, of course, was the critical insight Michael Klausner and Marcel Kahan pressed in highlighting the potential for network externalities in the choice of corporate charter terms. ${ }^{167}$ Given such network externalities, they argued, an individual firm's selection of particular terms might or might not suggest their efficiency. ${ }^{168}$ Mere individual consent, once again, may tell us less than we commonly think.

between constraint and coercion. See MARGLIN, supra note 15, at 70; see also Timothy L. Fort \& James J. Noone, Banded Contracts, Mediating Institutions, and Corporate Governance: A Naturalist Analysis of Contractual Theories of the Firm, LAW \& CONTEMP. PrOBS., Summer 1999, at 163, 184.

164 See Fort \& Noone, supra note 163, at 165, 177-78.

165 We might likewise question conventional attitudes toward entity theories of the firm. See Eric W. Orts, The Complexity and Legitimacy of Corporate Law, 50 WASH. \& LEE L. REV. 1565, 1567-1612 (1993).

166 Cf. Armen A. Alchian \& Harold Demsetz, Production, Information Costs, and Economic Organization, 62 AM. ECON. REv. 777, 794 (1972); Ronald H. Coase, The Nature of the Firm, 4 ECONOMICA 386, 390 (1937).

167 See Marcel Kahan \& Michael Klausner, Standardization and Innovation in Corporate Contracting (or "The Economics of Boilerplate"), 83 VA. L. REV. 713, 716 (1997); Klausner, supra note 12 , at 765 . Incorporation or re-incorporation in Delaware may thus have far less to do with individual choice and consent than with the surrounding social context, and particularly its network characteristics.

168 The failure of Klausner's and Kahan's analysis to put any significant dent in the corporate literature's continued reliance on nexus of contracts theories of the firm may suggest the continued unwillingness of law and economics to integrate interdependence into its analysis. 


\section{B. Change and Evolution in Law and Economics}

Beyond distortions in the implications we derive from consent, a further consequence of methodological individualism in law and economics may be a relative inattention to change, evolution, and dynamic effects more generally. Law and economics has thus largely oriented itself to static analyses of one sort or another. As Ronald Coase concisely states it, "the way we look at the working of the economic system has been extraordinarily static . . ."169 Others have echoed as much, highlighting law and economics' "focus[] on the present" and weakness in "explain[ing] circumstances that change over time,"170 and criticizing its use of "highly reductionist and static neoclassical models that abstract severely from essential features of the human condition and the social process." 171

Consider, for example, the relative inattention of law and economics to questions of where markets come from. Rather than analyze the latter, the literature simply assumes the existence of markets, as something in the state of nature. ${ }^{172}$ As a result, important issues - including the role of law in facilitating the emergence of markets, and potential distortions in the contours of certain markets - have received inadequate attention. ${ }^{173}$

We might find further evidence of law and economics' failure to attend to change in its assumption of static preferences. ${ }^{174}$ We have already seen how the discipline seeks to exogenize preference formation in the name of methodological individualism. ${ }^{175}$ The next step - to an assumption of fixed preferences - follows naturally. Microeconomics' study of individual utility is grounded in relevant preferences. If the discipline cannot speak to preference formation, however, it becomes necessary for it to hold the preferences constant. ${ }^{176}$

\footnotetext{
169 Ronald Coase, The New Institutional Economics, 88 AM. ECON. REv. 72, 73 (1998).

170 Anita Bernstein, Whatever Happened to Law and Economics?, 64 MD. L. REV. 303, 323 n.118 (2005).

${ }^{171}$ Gregory Scott Crespi, Exploring the Complicationist Gambit: An Austrian Approach to the Economic Analysis of Law, 73 Notre Dame L. ReV. 315, 383 (1998). One might, in fact, cast the entire emphasis of neoclassical economics on equilibrium along these lines. See supra notes 69-72 and accompanying text.

172 Ron Harris, The Encounters of Economic History and Legal History, 21 LAW \& HIST. REv. 297, 300 (2003) ("Markets were considered the natural state of things. They were presumed to have always been there.").

173 See Robert B. Ahdieh, Making Markets: Network Effects and the Role of Law in the Creation of Strong Securities Markets, 76 S. CAL. L. REv. 277, 280-81 (2003); Amitai Aviram, A Paradox of Spontaneous Formation: The Evolution of Private Legal Systems, 22 YALE L. \& POL'Y REV. 1, 10 (2004).

174 See Ellickson, supra note 2, at 540.

175 See supra Part I.C.

176 Behavioral law and economics' notions of dynamic inconsistency, to be sure, represent some challenge to the assumption of stable preferences. Even behavioral analysis, however, remains committed to methodological individualism, see Rostain, supra note 24 ,
} 
An account of preferences as exogenous and fixed, however, leaves a great deal on the cutting room floor. In many circumstances, preference formation is the central question of interest. ${ }^{177}$ In the study of network effects, for example, the critical issue is how the consumption patterns of collectives shape the preferences of individuals. ${ }^{178}$ The orientation of the social choice literature to the aggregation, rather than the shaping, of preferences might be understood in a similar light. But for an insistent individualism, issues of preference formation would seem like a natural focus for students of social choice. ${ }^{179}$

To related effect is law and economics' inattention to the evolution of norms. ${ }^{180}$ Notably, this has been true even of the social norms literature, which has largely black-boxed questions of how norms change. ${ }^{181}$ Some have explored these questions, to be sure - under the rubric of the "expressive" functions of law and otherwise. ${ }^{182}$ Yet one might have expected these questions to have received far more attention than they have, given their direct relevance to so much of what norms serve to accomplish.

Beyond the lack of attention to preference formation and norm change, law and economics has also eschewed the focus on change implicit in historical and evolutionary analysis. Douglass North - highlighting the need for economists to study history - has suggested the nexus between history and change: "The objective of research in the field [of economic history] is [to provide] an analytical framework that will enable us to understand economic change." 183

This was not, however, the tradition of economic analysis on which law and economics was built. Instead, law and economics emerged from what is arguably the least historical - and most disconnected - strand of economic theory: neoclassical economics. Law and economics emerged, thus, at the

at 973 , and is static in its own ways, see Jonathan Klick \& Gregory Mitchell, Government Regulation of Irrationality: Moral and Cognitive Hazards, 90 MINN. L. REV. 1620, 1627 \& n.20 (2006). Other strands of economic analysis have also taken steps beyond the assumption of static preferences, including certain work in institutional economics. Such efforts, however, are - by a wide margin - the exception rather than the rule.

177 See Dau-Schmidt, supra note 36, at 396.

178 See supra Part II.B.

179 See MARGLIN, supra note 15, at 69.

180 See Harris, supra note 172, at 332 ("Only rarely did law and economics scholars ask how legal norms evolved.").

181 Cf. Ellickson, supra note 2, at 550.

182 See, e.g., Cass R. Sunstein, On the Expressive Function of Law, 144 U. PA. L. REV. 2021, 2022-24 (1996); see also Kenneth G. Dau-Schmidt, An Economic Analysis of the Criminal Law as a Preference-Shaping Policy, 1990 DUKE L.J. 1, 37 ("[C]riminal punishment is not merely the price of crime, but is also an expression of society's condemnation of the criminal act ...."); Ellickson, supra note 2, at 550 (discussing relevant work of Randy Picker in the context of coordination).

183 See Douglass C. North, Economic Performance Through Time, 84 AM. Econ. REV. 359,359 (1994). 
lowest ebb in the discipline's attention to history, time, and change. ${ }^{184}$ Perhaps for this reason, law and economics' approach to history has often been characterized by disinterest and dismissal. ${ }^{185}$

To similar effect is the inattention of law and economics to evolutionary dynamics, which - like the study of history - require analysis beyond the individual. Notably, this inattention persists even in areas such as behavioral law and economics, which would seem especially well-suited to evolutionary analysis. ${ }^{186}$ Such disregard, however, was hardly predestined. In its very earliest iterations, law and economics was tied to the original, early TwentiethCentury literature of institutional economics. ${ }^{187}$ That original strand of institutional economics, meanwhile, was highly evolutionary in its emphasis, given the strong influence of Darwin's work on its founder, Thorstein Veblen. ${ }^{188}$ Modern law and economics, however, has emphatically disavowed any link to this "old" institutional economics. 189

Even more striking may be the failure of law and economics to attend to the evolutionary approach of Friedrich Hayek. ${ }^{190}$ Hayek has been a mainstay of the law and economics literature, commonly cited in support of the power of markets, as well as a strong individualistic focus. ${ }^{191}$ Yet Hayek's analysis was no less evolutionary in its orientation.

Hayek's application of theories of evolution to economics, moreover, did not rely on the individual selection models that dominate evolutionary theory today. ${ }^{192}$ Hayek saw evolution as playing out in the selection behavior of groups, rather than individuals. ${ }^{193}$ Echoing as much, law and economics might

184 See Harris, supra note 172, at 331 ("Law and economics applied those parts of microeconomic theory that were most ahistorical and static.").

185 See Harris, supra note 22, at 671-72.

186 See Keith N. Hylton, Calabresi and the Intellectual History of Law and Economics, 64 MD. L. REV. 85, 101 (2005). The work of Jack Hirshleifer constitutes a particularly prominent exception. See, e.g., Jack Hirshleifer, Evolutionary Models in Economics and Law: Cooperation Versus Conflict Strategies, 4 RES. L. \& ECON. 1, 3-4 (1982).

187 See Robert E. Scott, The Rise and Fall of Article 2, 62 LA. L. REV. 1009, 1027-28 (2002).

188 See Steven G. Medema et al., Institutional Law and Economics, in ENCYCLOPEDIA OF LAW AND ECONOMICS 418, 421-22 (Boudewijn Bouckaert et al. eds., 2000).

189 See, e.g., Richard A. POSNER, OVERCOMING LAw 427 (1995).

190 See F.A. HAYEK, KNOWLEDGE, EVOLUTION AND SOCIETY 7 (1983); HAYEK, supra note 34 , at 72 (asserting that "rules of individual conduct have developed because the individuals have been living in groups whose structures have gradually changed").

191 See, e.g., Ronald Chen \& Jon Hanson, The Illusion of Law: The Legitimating Schemas of Modern Policy and Corporate Law, 103 MICH. L. REV. 1, 12-17 (2004) (summarizing Hayek's numerous contributions to law and economics); Todd J. Zywicki \& Anthony B. Sanders, Posner, Hayek, and the Economic Analysis of Law, 93 lowA L. REV. 559, 561-563 (2008) (introducing an analysis of Hayek's impact on modern law and economics).

192 But see SOBER \& WILSON, supra note 49.

193 See Zywicki \& Sanders, supra note 191, at 579. 
do well not simply to attend to evolutionary change generally, but specifically to change among groups. To do so, however, the discipline would need to move beyond a continued insistence on methodological individualism.

To be sure, the law and economics literature has given some attention to change, history, and evolution. But this treatment has been the exception rather than the rule. ${ }^{194}$ This should not surprise us, however, given the methodological individualism of the discipline. Given how little an individualistic analysis can contribute to an understanding of the inherently social dynamics of change, a methodologically individualist law and economics simply does not have much to say about preference formation, norm change, or historical and evolutionary analysis. ${ }^{195}$

Consider, again, the issue of preference formation: static preferences can plausibly be seen as individual, rather than collective, in nature - i.e., not as a product of "social utility" in some abstract sense. On the other hand, it seems difficult to conceptualize the formation of preferences other than from a social perspective. What we value, and how we value it, is quite commonly collective in nature. To understand changes in preferences, then, attention to social and institutional factors, to culture, and to history is essential. Little wonder, then, that a methodologically individualist law and economics would avoid the subject.

\section{The Regulation of Knowledge and Information}

Given the social nature of the generation and transfer of knowledge and information, effective regulation in the area must attend to the collective and institutional dynamics at work. ${ }^{196}$ Consider, for example, the particular questions of trust that arise in the context of information goods. By comparison with other goods, the value of information goods depends heavily on trust - in its source, in its quality, and so on. The result is a heightened scope of uncertainty, the resolution of which - as described above - is

194 Some law and economics scholars, for example, have engaged in close historical analysis. See Daniel M. Klerman, Statistical and Economic Approaches to Legal History, 2002 U. ILL. L. Rev. 1167, 1168-70 (reviewing relevant work). One might also note relevant work on path dependence in this vein. See, e.g., Mark J. Roe, Chaos and Evolution in Law and Economics, 109 HARV. L. REV. 641, 641 (1996). The most significant exception, however, is the early law and economics literature's exploration of the efficiency of the common law. See, e.g., Paul H. Rubin, Common Law and Statute Law, 11 J. LEGAL STUD. 205, 210-11 (1982). This body of work was all about history and evolution. By the account of most historians, however, it was not particularly good history. See Harris, supra note 22 , at $669-70$. More importantly, it was directed to a distinctly narrow species of change. Id.

195 See MARGLIN, supra note 15 , at 68 ("[T] . .).

${ }^{196}$ See supra Part Il.D. 
necessarily social in nature. ${ }^{197}$ Any regulatory regime directed to information goods must recognize as much.

The public goods and network qualities of knowledge and information likewise dictate a more social orientation in relevant regulation. Information is non-rival and non-excludable, like other public goods. ${ }^{198}$ At the extreme, it exhibits the peculiar characteristics of a zero marginal cost good. ${ }^{199}$ Scarcity, as a result, looms less large in the production and consumption of knowledge and information, allowing - and even inviting - more collective modes of analysis. ${ }^{200}$ Network dimensions are likewise in evidence, especially where relevant knowledge or information is standards-based. Standards, like norms, are essentially defined by their social character and necessarily must be approached as such. ${ }^{201}$ A regulatory regime engaged only with the individualistic dimensions of relevant standards thus overlooks a great deal of the dynamic at work. 202

Yochai Benkler taps into just these challenges in his criticism of prevailing approaches to information regulation. ${ }^{203}$ Where wealth takes the form of knowledge and is socially produced, Benkler suggests, caution is required in the design of operative regulation. Regulators must take care to ensure that their efforts to insulate particular spheres, or to discriminate among potential participants in collective endeavors, do not undermine the social dynamics at work.204 Given the rapid pace of change, meanwhile, a "wait and see" approach may be in order, minimally to avoid the abuse of public interventions to advance private interests, and more generally given still-high levels of uncertainty in relevant settings. ${ }^{205}$ Finally, regulators must resist attempts to leverage copyright to limit innovation in emerging network settings. ${ }^{206}$

Julie Cohen likewise critiques our individualistic approach to knowledge and information in the context of copyright, pointing to distortions that may

\footnotetext{
197 See supra notes 124-129 and accompanying text.

198 See Avery Katz, Taking Private Ordering Seriously, 144 U. PA. L. REv. 1745, 1749 (1996).

199 See Henry E. Smith, Institutions and Indirectness in Intellectual Property, 157 U. PA. L. REV. 2083, 2116 (2009).

${ }^{200}$ See Yochai Benkler, The Wealth of Networks: How Social Production TRANSFORMS MARKETS AND FREEDOM 99-106 (2006).

201 Cf. Cohen, supra note 118 , at 1818.

202 An individualistic focus may also help explain the lack of regulation in certain information-driven spheres, including the internet. See Philip J. Weiser, The Future of Internet Regulation, 43 U.C. DAVIS L. REV. 529, 532-35 (2009).

203 See BENKLER, supra note 200, at 439-44.

${ }^{204} \mathrm{See}$ id. at 383-85. One might recall, in this vein, Arrow's concerns about the distortions attendant to an individualistic approach to knowledge. See Arrow, supra note 1, at 6-7.

205 See BENKLER, supra note 200 , at 26-27.

206 See id. at 439-41.
} 
arise from an inattention to the dynamic patterns at work. 207 Law and economics' preference for a static approach, directed to the analysis of "isolated goods at a particular point in time," is thus "especially perverse" "as applied to information goods."208 Copyright law must attend to the dynamic consequences of relevant rules as well, if it is to manage the pattern of positive feedback that arises where "exposure to information shapes demand for additional information," and if it is to appreciate the implications of institutional design generally for information production. ${ }^{209}$

\section{Crisis and Coordination in the Financial Markets}

A final area in which one might observe distortions attendant to methodological individualism is the realm of financial regulation. In understanding aspects of the financial markets - and in the design of relevant regulation - the necessary approach may often be more collective than individual. Consider, by way of example, the recent financial crisis.

There has been much discussion of the causes of the crisis. ${ }^{210}$ For the most part, however, this analysis has failed to focus on its central feature: the collective dynamics that lie behind the emergence - and the potential avoidance - of financial crises. The pattern at work in financial crises, properly understood, is one of multiple equilibria. ${ }^{211}$ The classic bank run helps to highlight as much.

In a bank run, crisis arises from the abrupt demand for withdrawals by a bank's depositors. Given the fractional reserve rules on which the banking system relies ${ }^{212}$ - under which capital reserves constitute only a small proportion of a bank's outstanding obligations - such withdrawal demands cannot be met, even by well-capitalized, healthy banks. They are quickly driven, as a consequence, into bankruptcy. ${ }^{213}$

Seeking to model this phenomenon, Douglas Diamond and Phillip Dybvig identified the critical characteristic of banking - and of bank runs - as the presence of multiple equilibria. ${ }^{214}$ In the superior equilibrium, depositors place

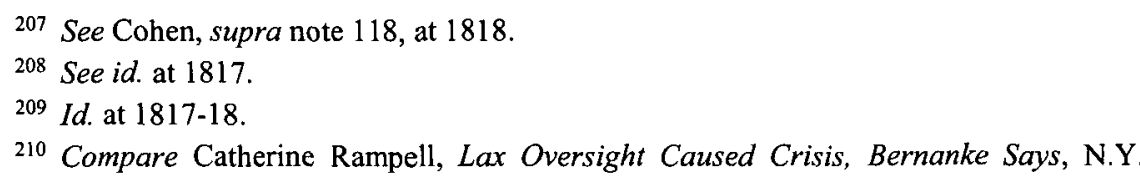
TIMEs, Jan. 4, 2010, at A1, with Floyd Norris, It May Be Outrageous, But Wall Street Pay Didn't Cause This Crisis, N.Y. TimEs, July 31, 2009, at B1.

211 See supra notes 110-111 and accompanying text.

212 See Mark J. Roe, Foundations of Corporate Finance: The 1906 Pacification of the Insurance Industry, 93 COLUM. L. REV. 639, 647 n.22 (1993).

213 See Robert F. Kornegay, Jr., Bank Loans as Securities: A Legal and Financial Economic Analysis of the Treatment of Marketable Bank Assets Under the Securities Acts, 40 UCLA L. REV. 799, 816 n.50 (1993).

214 See Douglas W. Diamond \& Philip H. Dybvig, Bank Runs, Deposit Insurance, and Liquidity, 91 J. POL. ECON. 401, 402 (1983) ("This vulnerability occurs because there are 
their funds with the bank, confident in their ability to withdraw on whatever future date they can make optimal use of the funds - allowing others to withdraw at earlier optimal dates and generating an efficient distribution of risk. $^{215}$ In the inferior equilibrium, by contrast, confidence is undermined, causing all depositors to seek immediate (and sub-optimal) withdrawal of their assets - and thereby breaking the bank. ${ }^{216}$ The essential dynamic of the banking system, then, is one in which coordination of depositors around a superior equilibrium generates optimal returns, while coordination around an inferior equilibrium brings financial ruin.

This multiple equilibrium dynamic is not unique, however, to banking. Rather, it plays out across the financial markets generally. ${ }^{217}$ Coordination is thus central to the operation of the modern financial markets. ${ }^{218}$ The benefits of a particular investment or trading system to a given individual are closely tied to its attraction to others. Variously framed analyses of "strategic complementarities,"219 "systemic risk,"220 and "herd behavior"221 in the financial markets bespeak, at root, their multiple equilibrium character. Where strategic complementarities are observed, for example, financial markets can be expected to operate like the banking system - with depositors collectively settling on either the equilibrium of maintaining deposits or of withdrawing them, based on their expectations of one another. ${ }^{222}$ To similar effect, outside

multiple equilibria with differing levels of confidence.")

215 See id.

216 See id. at 403.

217 See Ahdieh, supra note 89, at 217-21; Russell Cooper \& Andrew John, Coordinating Coordination Failures in Keynesian Models, 103 Q.J. ECON. 441, 447 (1988) (highlighting "the connection between strategic complementarity and multiplicity of equilibria"); Paul R. Masson, Multiple Equilibria, Contagion, and the Emerging Market Crises 5 (Int'1 Monetary Fund, Working Paper No. WP/99/164, 1999) (identifying distinct accounts of multiple equilibria in financial markets); see also id. at 3 ("[M]odels with multiple equilibria . . . square better with the stylized facts of global financial markets.").

218 See Masson, supra note 217, at 6 ("[1]f each bank believes that all other banks will stop lending, all banks will stop lending." (quoting Jeffrey Sachs, Theoretical Issues in International Borrowing, in PRINCETON STUdies IN INTERNATIONAL FINANCE No. 54, at 32 (July 1984))).

219 See Cooper \& John, supra note 217, at 447.

220 See Steven L. Schwarcz, Systemic Risk, 97 GEO. L.J. 193, 194 (2008).

221 See Christopher Avery \& Peter Zemsky, Multidimensional Uncertainty and Herd Behavior in Financial Markets, 88 AM. ECON. Rev. 724, 724 (1998); cf. Paul Krugman, A Model of Balance-of-Payment Crises, 11 J. MONEY, CREDIT \& BANKING 311, 314-15 (1979) (analyzing conditions for equilibrium in balance-of-payment crises). The analysis of network effects in the financial markets might also be included in this litany. See, e.g., Ahdieh, supra note 89, at 273-84.

${ }^{222}$ See Cooper \& John, supra note 217, at 447; see also Satyajit Chatterjee et al., Strategic Complementarity in Business Formation: Aggregate Fluctuations and Sunspot Equilibria, 60 REV. ECON. STUD. 795, 809 (1993). 
the bank run context, banks will tend to lend or refuse to lend as a group; hedge funds and private equity firms will hold back or aggressively compete for investment opportunities in tandem. Herd behavior operates similarly, with the pack moving either to a high-level or low-level equilibrium, depending on expectations. ${ }^{223}$

An approach to financial crises grounded in the analysis of individuals is likely, as a result, to lead us astray. Most simply, it may do so given the relative under-emphasis of individual-oriented regulation on change - and the centrality of change (and rapid change) to financial crises. ${ }^{224}$ Even more fundamental an issue, however, is the inability of an individualistic approach to grapple with the multiple equilibrium dynamic at work, ${ }^{225}$ and the consequent prospect that relevant law and regulation may downplay that dynamic. An individualistic approach may thus cause us to miss the essence of the process at work.

Within a multiple equilibrium approach to the financial markets, we have seen, crises occur when the market moves - necessarily abruptly - from a high-level to a low-level equilibrium of lending, investment, and spending. Banks refuse to lend. ${ }^{226}$ The market for credit default swaps disappears. ${ }^{227}$ Private equity investment dries up. ${ }^{228}$ And we find ourselves exactly where we were amidst the recent financial crisis. Why exactly do banks, traders, private equity firms, and others do this? Because their decision-making is fundamentally social in nature. In the emergence of a crisis, each bank, trader, and private equity firm determines that they expect other individuals and institutions to cut back their lending, investing, and spending. Given the multiple equilibrium dimension to their returns, in turn, they elect to do so as well.

The immediate cause of the recent financial crisis, then, was not any of the many culprits we have since targeted, including subprime lending, excessive risk-taking, the housing bubble, and the like. ${ }^{22}$ Rather, it is the shift in collective expectations from a high-level to a low-level equilibrium of lending, investment, and spending. The solution to financial crises, in turn, lies in

223 See supra note 221. Herd behavior arises from the tendency of investors to follow market trends, and consequently to overvalue or undervalue relevant assets. See Schwarcz, supra note 220, at 217; see also Abhijit V. Banerjee, A Simple Model of Herd Behavior, 107 Q.J. ECON. 797, 798 (1992).

224 See supra Part III.B.

225 See supra notes 111-112 and accompanying text.

226 See Edmund L. Andrews, Fed Offers Wall St. Banks New Loans to Ease Crisis, N.Y. TIMES, Mar. 12, 2008, at Al.

${ }^{227}$ See Serena Ng, Credit-Default Market Freezes as Risk Grows, WAll St. J., Sept. 19, 2008 , at C3.

228 See Phil Craig, Party is Over for Hedge Funds, Wall St. J., Jan. 26, 2009, at C3.

229 See supra note 210 and accompanying text. 
shaping collective expectations to the contrary. As to this critical endeavor, however, individual analysis does not tell us very much.

The methodological individualism of law and economics may thus variously distort our analysis of consent, diminish our attention to change, and misdirect our approach to the regulation of information and the financial markets. Significant as they are, moreover, these are simply examples of the potential consequences of an individualistic approach. In their emphasis on both individuals and community, Parchomovsky and Siegelman suggest yet other potential implications - for environmental and tort law, for our approach to takings, and for our understanding of collective action. 230 Methodological individualism may also cause us to pay inadequate attention to the hierarchical dynamics created by legal relationships within the firm, and hence to reach flawed conclusions as the need for mandatory fiduciary duties, limits on executive compensation, and the like.231 Yet further consequences of law and economics' methodological individualism, finally, might be the potential to overestimate the role of the law, ${ }^{232}$ to focus too strongly on Pareto optimality, ${ }^{233}$ and to favor less complex accounts of valuation.234 It becomes clear, then, that if we are to engage fully with important - and perhaps increasingly important - areas of legal and economic analysis, we must move beyond the rote methodological individualism on which law and economics has traditionally relied.

\section{CONCLUSION}

It bears emphasizing, by way of conclusion, that the foregoing is not intended to dispute the significant benefits of methodological individualism. At a minimum, methodological individualism discourages descriptive ambiguity and helps to generate more readily testable propositions. By comparison with methodological holism, it may also help us avoid overlooking important facets of particular social and economic interactions. ${ }^{235}$

230 See Parchomovsky \& Siegelman, supra note 19, at 124-42.

231 See Eric W. Orts, Shirking and Sharking: A Legal Theory of the Firm, 16 YALE L. \& POL'y REV. 265, 266-67, 270 (1998). Beyond the substantive distortions enumerated above, a persistent methodological individualism may also have important scholarly consequences, including inadequate attention to some of phenomena described above, and a failure to appreciate the important connections among them.

232 See Parchomovsky \& Siegelman, supra note 19, at 82, 108.

233 See Russell Hardin, Magic on the Frontier: The Norm of Efficiency, 144 U. PA. L. REV. 1987, 1991 (1996).

234 This is the pattern at work, for example, where the importance of network effects is downplayed. See, e.g., supra notes 167-168 and accompanying text.

235 Elster grounds his argument in favor of methodological individualism - and his rejection of Marxist class analysis - in just this concern. See Elster, supra note 51, at 453- 
As we have seen, however, methodological individualism has equally significant limits. On its own, it is not sustainable as an analytical method. As Kenneth Arrow observed, criticizing his fellow economists' methodological individualism, "every economic model one can think of includes irreducibly social principles and concepts." 236 This result does not, moreover, turn on the inadequacy of the given models. Rather, it is an unavoidable consequence of the analysis. As Arrow concludes: "[I]ndividual behavior is always mediated by social relations. These are as much part of the description of reality as is individual behavior."237

Methodological individualism's mere aggregation of individual utilities, meanwhile, misses too much, in too many areas. ${ }^{238}$ As Lars Udehn puts it: "Social structure takes the form of a set of interdependent positions that are prior to the interaction between the individuals occupying these positions. . . . [T] his means that to talk about 'aggregation' is misleading: 'for the phenomena to be explained involve interdependence of individuals' actions, not merely aggregated individual behavior." 239 In important areas of social and economic interaction, thus, the whole really is more than the sum of its parts.

Given as much, an effective methodology must integrate both individualistic analysis and attention to relevant social, collective, and institutional factors. ${ }^{240}$ As Timothy Fort and James Noone emphasize, an account in which "economic action is the determined result of social kinship patterns ... provides an oversocialized view of human nature, while [an] atomized view provides an undersocialized view. Instead, persons have a dual nature: We both are constrained and informed by our communitarian norms and retain an ability to transcend that community." 241 Some "duality" of explanation is consequently required. ${ }^{242}$

54, 468. Methodological individualism may also have deeper analytical benefits, however, including focusing our attention on the actual place where human experience occurs. See Rubin, supra note 41 , at 1717.

${ }^{236}$ Arrow, supra note 1, at 2.

${ }^{237} \mathrm{Id}$. at 5 .

${ }^{238}$ Contrary to individualistic accounts, thus, it is not the case that "once the appropriate signals are given, individuals behave in isolation and the result of their behaviour may simply be added together." See Kirman, supra note 119, at 137 . In a related vein, one might note Kirman's reliance on the Sonnenschein-Mantel-Debreu theorem to critique the project of aggregation - and of macroeconomics - more generally. See Alan P. Kirman, Whom or What Does the Representative Individual Represent?, J. ECON. PERSP., Spring 1992 , at 117, 121-22.

239 Udehn, supra note 28, at 494 (quoting COLEMAN, supra note 65, at 22).

${ }^{240} \mathrm{Cf}$. Jon Elster, Explaining SOCial Behavior: More Nuts and Bolts for the SOCIAL SCIENCES 6 (2007).

${ }^{241}$ Fort \& Noone, supra note 163, at 185; see also Andrew J. Cappel, Bringing Cultural Practice Into Law: Ritual and Social Norms Jurisprudence, 43 SANTA CLARA L. Rev. 389, $394 \mathrm{n} .10$ (2003) ("Indeed, too sharp a dichotomy between methodological individualism and holism appears problematic under careful analysis. ... [W] hat needs to be explained is the 
The critical project for law and economics, then, is to develop an approach that captures the individual in her social context. In attempting as much, we might take our cue from others' efforts in this vein. Most familiarly, we might see this as the place where Hayek ultimately found himself - "replac[ing] his customary methodological individualism with a group theory approach, as he attempted to shed some light on the evolution of systems of rules of conduct." 243 Hayek's analysis was thus individualistic, yet also institutional, in that it recognized the potential for social and institutional factors to play a causal role. ${ }^{244}$

The evolutionary selection of rules of individual conduct [was], in Hayek's view, a process that operates not through individual action but 'through the viability of the [group] order it will produce ....' [T] he relationship between the parts that form a group, and which are therefore essential to the existence of the group as a whole, cannot be fully explained by the mere interaction between the parts. ${ }^{245}$

Given Hayek's prominent place in law and economics - including because of his strong individualism - his perspective may offer particularly useful inspiration for a shift beyond methodological individualism. We might also gain insight from other sources, however, including the work of James Coleman, who sought to bridge the holistic approach of sociology with the methodological individualism of economics. ${ }^{246}$

In Coleman's framework diagrams, thus, there is recognition of the critical place of individual preferences in determining individual behavior, as well as the role of individual behavior in shaping social outcomes. ${ }^{247}$ There is equal recognition, however, of the important role of social context in shaping preferences, and even of its role in defining the framework within which individual behaviors combine and interact to produce social outcomes of interest.

complex interrelationship between the two.").

242 See Hodgson, supra note 9, at 222. As Arrow puts it: "I have emphasized the desirability of an individualist perspective. I now want to argue that economic theories require social elements as well even under the strictest acceptance of standard economic assumptions." Arrow, supra note 1, at 4.

243 Amstutz, supra note 34, at 468-69.

244 See Paul N. Cox, The Public, the Private and the Corporation, 80 MARQ. L. REV. 391, 436 n.142 (1997).

${ }^{245}$ Amstutz, supra note 34, at 469 (citations omitted) (quoting HAYEK, supra note 34, at 68).

246 See COLEMAN, supra note 65; see also Ellickson, supra note 2, at 542 . Wider attention to Akerlof and Kranton's identity economics, see supra note 21 and accompanying text, would also be in order. See Kaushik Basu, Prelude to Political Economy: A Study of THE SOCIAL AND Political Foundations of ECONOMICS 255-56 (2000).

${ }^{247}$ See supra notes 62-63 and accompanying text. 
With such a framework, there is no insistence on starting with - or reifying the place of - individuals in the analysis. Quite obviously, individuals are central to the method. But there is no less a role for social and institutional elements, in seeking to understand relevant social and economic phenomena. With such an approach, law and economics would continue to attend to the individual, but would be attentive to her context as well. 